Portland State University

PDXScholar

$11-4-2008$

\title{
At Home in the World : the American Middle-Class House as a Twenty-First Century Public Square
}

Kathleen Holt

Portland State University

Follow this and additional works at: https://pdxscholar.library.pdx.edu/open_access_etds

Part of the Creative Writing Commons, and the Sociology Commons

Let us know how access to this document benefits you.

\section{Recommended Citation}

Holt, Kathleen, "At Home in the World : the American Middle-Class House as a Twenty-First Century Public Square" (2008). Dissertations and Theses. Paper 3982.

https://doi.org/10.15760/etd.5863

This Thesis is brought to you for free and open access. It has been accepted for inclusion in Dissertations and Theses by an authorized administrator of PDXScholar. Please contact us if we can make this document more accessible: pdxscholar@pdx.edu. 


\section{THESIS APPROVAL}

The abstract and thesis of Kathleen Holt for the Master of Arts in Writing were presented November 4,2008 , and accepted by the thesis committee and the department.

COMMITTEE APPROVALS:

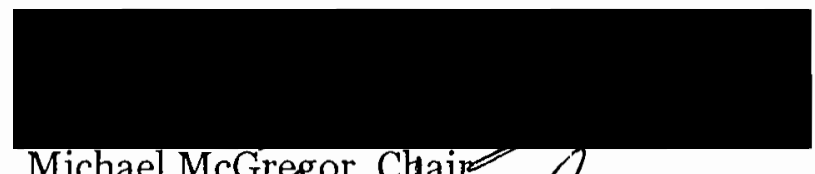

$$
\text { Michael McGregor, Chain /la }
$$

DEPARTMENT APPROVAL:

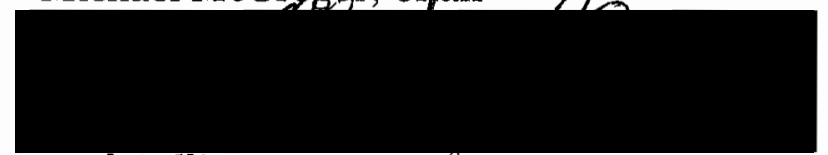

$$
\text { Paul Collins }
$$

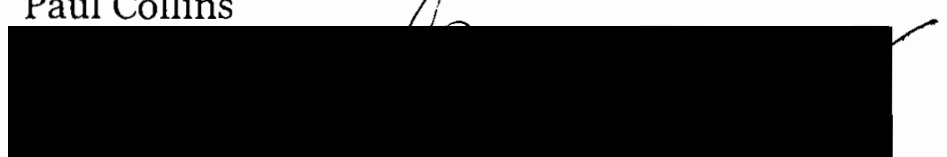

Qebra Gwartney

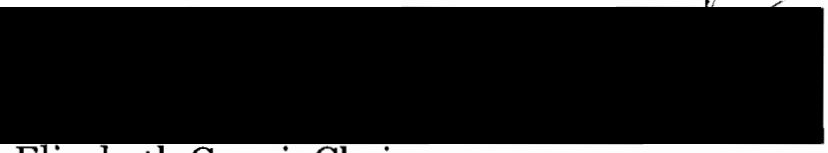

Elisabeth Ceppi, Chair

Department of English 


\section{ABSTRACT}

An abstract of the thesis of Kathleen Holt for the Master of Arts in Writing presented November 4, 2008.

Title: At Home in the World: The American Middle-Class House as a Twenty-First Century Public Square

Using personal narrative, interviews, and research, this thesis project looks at how the middle-class American home has been transformed, by people like me, into a modern-day public square.

The first part of the book looks at the phenomenon of home ownership and subsequent financial investments in domestic goods. It also uses Jurgen Habermas's theory of the public sphere to define the notion of "public" as ideological as well as physical. This thesis ultimately contends that deliberate and conscientious investments (or disinvestments) in domestic goods and services may be read as social and political stands (i.e., voting with one's dollars). Later chapters consider examples of how activities using the home are public acts, particularly remodeling, blogging and social networking, and urban homesteading.

The narrative of the book follows my family's life in one particular house and neighborhood, exploring our growing awareness of the importance of using our private lives to become public citizens. 


\section{Acknowledgments}

I am obligated to many people who helped make the going on this years old project a little easier. First, thanks to my thesis advisor, Michael McGregor, who encouraged me when I first began this project several years ago in one of his classes, waited patiently as I tended to my young child and burgeoning career, then, when I was ready to get back to work on this book, pushed me at every step to think harder and write better.

Thanks also to my other thesis committee members: the accomplished and insightful Paul Collins, whose astute remarks and suggestions will guide me through the next steps of attempting to revise, complete, and publish this work; and the brilliant and generous Debra Gwartney, who, for years, has been a dear friend, critical reader, and personal and professional role model.

I deeply appreciate the many good friends who listened to my stories and ideas over the years-during coffee breaks, phone calls, play dates, potlucks, and parties. Special thanks to my talented writer friends Dan DeWeese, Apricot Irving, Kristin Kaye, Jamie Passaro, Beth Piatote, Mary Rechner, and Matthew Kauffman Smith, each of whom has spent time reading my work or helping me think through and improve this manuscript. As my defense date neared, a network of families-notably the Kauffman Smiths, Kayes, Rensmiths, Sheets, and Wrights-kept my child (and, sometimes, my husband) entertained and fed. 
Thanks also to my colleagues at the Oregon Council for the Humanities, whose razor-sharp wits, keen critical minds, and overall intellectual ferocity are daily inspirations.

I was lucky to find so many people in Portland who are consciously living public lives through their private homes, and I thank each and every one of them for spending time with me so that I could better understand what such a life looks like.

And, of course, my deepest gratitude and love to Stella, who patiently waited for me to complete this project, sometimes quietly watching me work through the glass-paned doors separating her playroom from my office; and to Alex, whose unflagging devotion and incomparable skills as a chef, home remodeler, playmate to Stella, and husband to me were the only reasons that this book has seen the light of day. 
'AT HOME IN THE WORLD:

THE AMERICAN MIDDLE-CLASS HOUSE AS A

TWENTY-FIRST CENTURY PUBLIC SQUARE

by

KATHLEEN HOLT

A thesis submitted in partial fulfillment of the requirements for the degree of

MASTER OF ARTS

in

WRITING

Portland State University

2008 


\section{Table of Contents}

Acknowledgments i

Introduction 1

Chapter One: A Piece of the Rock 8

Chapter Two: The Public House 25

Chapter Three: The Home Laboratory 48

Chapter Four: Mommy Power 71

Chapter Five: Green Acres in the City 88

Conclusion 110

Works Cited 116 


\section{Introduction}

When my husband Alex and I headed out in the evenings after work or first thing on weekend mornings in the spring of 2002, we assumed classic househunting positions: Alex behind the wheel and me riding shotgun, in charge of holding coffee cups and half-eaten jelly donuts. With the Thomas Guide open on my lap, I navigated us through the more affordable sections of Portland while watching for realtor signs dangling from hangman-style posts. At promising houses, we pulled over and I jumped out to grab flyers from their flimsy plastic holders. On each I wrote the date and quick notes-"busy st." "cute!" "backs up to parking lot." When we got home, I organized them in an expanding folder so we could pore over them like wedding photos.

We knew exactly what we wanted-a pre-World War II house with at least two bedrooms, hardwood floors, and original fixtures-but what we didn't know, what we never asked each other, was why: not only why this kind of period house, but why buy at this time in our lives, when Alex was just beginning a new career and I was cobbling together freelance work while going to grad school.

After all, most of the economic news in 2002 was bad: Interest rates were dropping though housing prices were steadily rising. Oregon boasted both the highest unemployment rate and among the highest home prices in the country. Nationally, a recent period of record home sales was also a period of 
record mortgage foreclosures. But there we were, Alex and I, caught up in the frenzied spring ritual of open houses and drive bys, ready to jump into the offers-clauses-counteroffers-exclusions-inspections-exceptions fray. On TV, Fannie Mae's commercials reminded us that they were in "the American Dream business." Neal Conan on Talk of the Nation discussed the rising costs of houses and asked listeners, "What are you willing to give up to afford your piece of the American Dream?” Newspapers reported that home ownership was at an all-time high-68 percent of Americans had their piece of the rock. We didn't want another day to go by without having ours.

We'd been homeowners before and loved it: not having to check with anyone before painting our kitchen burgundy and peach, or pulling up a third of the back yard to add flower and vegetable gardens. Even downsides-having to repair a broken window or crawl under the house to investigate a strange smell-weren't so bad. These kinds of maintenance and home improvement chores were decidedly middle-class-an affiliation we didn't realize we'd effectively lose after we sold our house in the college-town of Eugene, Oregon, to move two hours north to Portland, where we rented a house, a charming bungalow with period details, but a rental nonetheless.

Although the housing market in Portland was more expensive than in Eugene and our monthly payments would be a stretch for the first few years, we had made a small profit from the sale of our first house and were eager to use those funds to buy our way back into the middle class. Because owning a home in America is more than just a historically sound investment: it is 
evidence that you have realized at least some small part of the American Dream-by hook or by crook, through inheritance or hard work or, as has become clear in the midst of 2008's economic downturn, an unstable system of loans.

But the truth of the matter is that home ownership has long been a bipartisan tool, used as a key figure in the narrative of American exceptionalism, which says that America is different and better than other nations because its citizens are united not merely by history and culture, but also by an ideology that success can be had by all, regardless of individual backgrounds and circumstances.

This narrative of exceptionalism was what motivated the rise of a class that writer David Brooks, in his 2000 book, Bobos in Paradise, described as mid-twentieth century anti-establishment liberals, people who broke through the generations-old stranglehold of Protestant elites at the country's best colleges and universities and then worked their way up various professional ladders to suddenly find themselves firmly on the upper and upper-middle class rungs of American society. Brooks says Bobos are "an elite that has been raised to oppose elites," and, because of this, are a conflicted lot-a socially enlightened, educated class that feels anxiety and guilt about their own wealth and participation in consumer culture.

Brooks adds that in response to this guilt, Bobos have devised a set of codes to both justify and regulate their participation in capitalism, “encouraging some kinds of spending, which are deemed virtuous, and 
discouraging others that seem vulgar or elitist." Virtuous spending might include buying old or handmade things that show craftsmanship and have "soul," or supporting small, local businesses over large, national chains.

Although we're about a half-generation shy of being official Bobos, Alex and I and most of our peers not only have college degrees and white-collar paychecks, we also have guilt and anxiety about our middle and upper-middleclass status, as well as our participation in consumerism and the effect this has on politics and democracy. Especially in 2008, when articles about economic and environmental disasters are daily on the front page of nearly every newspaper in the country, we are a group for whom that guilt and anxiety has been translated into the way we see and use our homes. For many of us, owning a home also means inheriting a set of social obligations to a community, whether to our neighborhood, region, or country. Our homes are not merely reflections of who we are: they are tools we use to broadcast our struggles and concerns.

Although this sense of the middle-class home as a political tool is visible in communities across the country, it is especially apparent in a city like Portland, Oregon. A darling of city planners, architects, civic leaders, restaurateurs, and Europhiles alike, Portland is portrayed by mainstream media as one of the "most livable" cities in America: greenest, cleanest, most sustainable, most bike friendly, and among the best places for eating, walking, having a baby, and making an independent movie. 
Portland is also considered generally affordable, especially compared to other livable cities like San Francisco and Seattle, because it's still possible for people who aren't "superrich" to buy a house within the city limits-in Portland's case, within the urban-growth boundary: another award-winning idea that regulates development and sprawl, preserves surrounding farm and forest lands, and, some say, contributes to overall livability.

And Portlanders possess a strong a sense of regional exceptionalism, which is steeped in a history that includes protectionism (most famously articulated by Governor Tom McCall's “visit but don't stay" remarks), public involvement (as seen in the state's landmark 1902 direct legislation processes of initiative and referendum), and social responsibility. All of these distinctions have triggered a twenty-first century westward expansion, attracting a steady stream of young people-dubbed the "creative class" by scholar Richard Florida-who bring with them optimism, creativity, and a strong sense of civic responsibility.

What happens when you mix Bobo guilt, a burgeoning creative class, a regional narrative of exceptionalism, $\mathrm{Al}$ Gore's inconvenient truth, and the largest economic downturn America has seen in decades? In broad, general strokes, you create a group of progressive-minded city dwellers like Alex and me who no longer see our homes solely as a place of isolation and retreat. We strive to be hands-on, conscientious, political citizens who buy local goods, eat seasonal produce, and make things with their hands. Of course, this runs a wide gamut: Some of us have given up their cars, grow much of our own food, 
and buy products from within one hundred miles of our homes. Others invest in green building and remodeling supplies and drive Priuses. Others buy mostly organic produce and eggs, use low-VOC paints, and grow native plants. But regardless of the various permutations, for most of us, our homes have become our laboratories where we experiment with materials and ideas, and canvases on which we communicate who we are and what we value.

In doing so, we justify what for many middle-class homeowners is the single largest purchase they'll ever make-one that can also be the straightest path to wealth, because, over time, investing in real estate is less risky than the stock market and more profitable than a savings account. In keeping with Brooks's theories of how Bobos rationalize some spending as virtuous, this process of justification includes renovating an old house with "soul," building a green house on an infill lot close to public transportation, or pulling up lawn to plant vegetables.

We twenty-first century homeowners are a chatty bunch. Our lives and thoughts are community affairs, discussed with strangers on blogs and listservs, or with friends and colleagues at work or the pub. Regardless of political affiliations, religious beliefs, professional expertise, and personal interests, house talk is the lingua franca of middle-class homeowners like me. We cluster with our neighbors on the corner and wonder how much the house across the street sold for. We offer referrals for contractors, preschools, and community-supported farms. We give our opinions on paint color, window treatments, wood floor finishes, and garden plants. All the while, we're 
exchanging a lot of coded information about who we are, what we value, what we believe, and what we hope for.

Through the middle-class acts of buying a home, remodeling it, raising a family, and planting a garden, Americans like me are struggling with myriad symbols: Is the home a patriotic investment that keeps capitalism alive, a private sanctuary that keeps us apart from the world, a public statement of who we are and in what we believe, or a political vehicle that expresses our support for or dissent from social and economic systems? 
Chapter One

A Piece of the Rock

Not once during our house-hunting frenzy did Alex and I discuss why we wanted the type of home that we were looking for. Neither of us had lived in an early-1900s house, though we somehow shared a longing for one. Alex grew up in a ranch house in a suburb of Denver. I was raised in a series of rentalsnone of them architecturally distinctive-in Hawaii. And the house we'd owned together in Eugene-the first for both of us-was a simple ranch with wood floors and a yard that went on and on.

So, where did our love of nine-foot ceilings and crown moldings came from? This longing for period light fixtures and glass doorknobs, honeycolored wood floors and leaded glass windows? We wanted all of this in about two-thousand well-designed square feet on a decent-sized lot on a quiet, treed street in a good neighborhood near parks and shops and restaurants, all for well under $\$ 200,000$. And a fireplace and porch would be swell.

Our realtor, Brad, stifled a yawn when we gave him the list. We were, after all, describing 90 percent of the housing stock on Portland's inner eastside, which was steadily and efficiently developed, block by block, over the late 1800 and early 1900s. Bungalows and Craftsman houses line up, one after another on every street on the grid, with handfuls of Colonials, Tudors, and Victorians thrown in for good measure. Brad tried to talk us into looking at a "tricked out" ranch he'd seen up in Cully, complete with finished 
basement, hot tub, and a wet bar, but our minds were made up. We should have felt more at home in the ranch, but, instead, we spent weeks looking for those telltale period details that comprised what we imagined as the perfect house.

We were not alone in our desires. Seattle architect Grant Hildebrand says that Americans are innately attracted to the small scale and craftsmanship of homes built before World War II. Many of these houses are similar in exterior appearances and have some of the same characteristics, but they were, for the most part, designed and built individually, unlike the rapid rise of suburban homes, described by singer Malvina Reynolds in the 1960s as "little boxes"-a critique not only of the architecture of those houses, but also of the lives of the people who chose to live in them, as homogenous and uninspired.

In her book Bungalow Nation, Diane Maddex says that between the early 1900 and 1930s, bungalows became the most popular house style in America as they gave middle-class Americans the chance to have "an affordable paradise of their own." Bungalows were simple, artistic, and democratic-altogether more reflective of middle-class values than ostentatious and ornate Victorians. "The lowly bungalow in fact became America's first national house type," she writes. "Inexpensive, simple to build, modern, and sited on a private plot of land, it was architecture for a democracy as envisioned by Frank Lloyd Wright in 1910: 'America, more than any other nation, presents a new architectural proposition, her ideal is democracy."” 
The suburban ranch house developments that followed at mid-century were created in a similar spirit of democracy and appreciated the needs of the American family to be ensconced in a home with a two-car garage and fenced back yard, but the bungalow is considered an American home, neither pretentious and fussy, nor mass-produced and lacking of character. Its history and craftsmanship, no matter how simple and inexpensive, still strike a chord in middle-class Americans.

Knowing Portland had entered the new millennium with a peaking sellers' market, where the best of these period houses were selling within days at tens of thousands of dollars above listing prices, I asked Brad, "Are we completely crazy? Do we even have a chance?"

"Oh sure," he said, doing his best to sound sincere. "But you'd better be ready to jump."

We were ready. We'd been warming up for weeks. By May, we knew the neighborhoods as if we'd platted the eastside ourselves: Humboldt, BoiseEliot, Kenton. King, Concordia, Beaumont. Richmond, Sunnyside, Buckman. We knew where to look. We knew what we wanted.

Because we were hungry, and old pros compared to the first-time homeowners we were competing with, we grew nimble and efficient: I did zip code searches on the Regional Multiple Listing Service website with such diligence that I found promising properties before Brad did, robbing him, he said, of the fun part of his job. Cruising through neighborhoods lost the sense of romance and adventure we'd known in the early days of our search: we 
barely slowed the car during drive-bys, wrinkling our noses as we passed an unacceptable house and moving quickly on to the next address on the list.

After a couple of failed offers, Alex and I finally bought a 1926 bungalow with hardwood floors and original fixtures on a tree-lined street in the Roseway neighborhood of northeast Portland. It wasn't the perfect house, but it had four bedrooms, a fireplace, built-ins, period moldings and fixtures, and it cost well under $\$ 200,000$. Although it needed some work, we were thrilled at the prospect of working together to create something new out of something old. True, the projects were more than just splashing some fresh paint on walls: the upstairs was barely finished with mismatched acoustic tiles on the ceiling and painted subfloors, the lawn was patchy and uneven with no landscaping to speak of, and the kitchen had barely any counter space and flimsy cabinetry.

But nothing inspires optimism like a new house-we felt like pioneers determined to turn a dry, hilly acre of land into Eden. Who isn't susceptible to the romance of the new? The thrill of a fresh turn of phrase, green eyes we've never before seen? For someone like me, who is tickled just watching new friend order a soy mocha topped with a dollop of whipped cream, something like a house that needs work can set my heart racing with anticipation.

But there were other problems: the house was farther out from downtown than we'd hoped and the only nearby shops were a Safeway, a Subway, and a couple of Asian food markets-thus, we remained dependent on our car if we wanted to reach the local vendors, restaurants, and amenities that 
comprised a true urban life. In addition, with its symmetrical façade and bare front lawn, our house was one of the plainer houses on the block. The house to the north was a 1912 Craftsman with an asymmetrical façade and multilevel eaves; the house to the south, a two-story 1905 shingle-style Old Portland with a large, front-facing gambrel dormer. Both had lush gardens instead of front yards and broad, welcoming wood porches, big enough for chairs and tables. On one hand, I was glad to be in such good company; on the other, I thought of our house as the homely sister in a family of beauties.

When I shared these extensive details with an acquaintance, she commented, "The Portland intellectual community knows way, way too much about bungalows." I laughed then, but later the subtext of her comment hit home: I, and many of my closest friends, had become incredibly preoccupied with real estate and the details of not just our houses, but each other's. Harvard professor Marjorie Garber, in her 2000 book Sex and Real Estate, describes real estate as "yuppie pornography," adding that ogling other people’s houses "is not only acceptable" but "absolutely de rigueur." Houses and especially gardens, she said, have "emerged as the baby boomers' chic new playgrounds."

Garber's remarks hint at the mechanisms at work behind home ownership and at the way our houses tell the stories of who we are and what we value. At one level, these stories are about aesthetics, reflecting our preferences for colors and styles, but at another level, they are about things that are harder to talk about in plain language: our house conversations 
describe our ambitions and desires, attempt to disguise our insecurities and failings, and even hint at our social and political beliefs. So regardless of our motivations, houses are more than just private physical spaces: they are public ideological expressions. And what we choose to do with them and how we choose to live in them are the most powerful stories we can tell about our conflicts with and acceptance of the American Dream.

This makes sense when you look at the history of the home, which, as we know it today, can be traced back to Europe's Middle Ages. In his 1997 book Home: A Short History of an Idea, Witold Rybczynski explains that the first inklings of the modern middle-class American home can be seen in the fourteenth century, not among the dwellings of the poor who lived in hovels or the rich who lived in castles, but among the merchants, tradesmen, and landowners of the bourgeois class who lived in townhouses with shops and businesses on the first floor and residences above.

These dwellings, viewed through contemporary eyes, were odd, liminal spaces, clearly domestic but also somewhat public. Life in these bourgeois homes played out in one large hall that was used for cooking, eating, sleeping, entertaining, and conducting business, where the homeowner, on a break from tending his shop below, might discuss matters with his employees while his children played underfoot and his wife and her sisters prepared supper. Rybczynski says that houses of this time were so full and busy because of the lack of public spaces: no coffee shops on every corner or pubs on every block. It wasn't unusual for up to twenty-five people to move through the home each 
day, including family members and servants, but also tenants, employees, and friends. "What mattered [in the Middle Ages] was the external world, and one's place in it," Rybczynski writes. "Life was a public affair, and just as one did not have a strongly developed self-consciousness, one did not have a room of one's own."

The very idea that houses were once so public is startling to Americans today, for whom the very notion of "home" implies privacy and intimacy. However, Rybczynski argues that the recognition of the smaller social denominations of "self" and "family" is fairly new, perhaps only a few hundred years old, yet deeply ingrained in the American mind as normal. And with this shift in human consciousness came a shift in the purpose of the home as "single-family detached."

Rybczynski goes on to explain that we must really look to the Netherlands in the seventeenth century to find a recognizable ancestor of the modern, Western home. Unlike other countries in Europe at the time, Holland was made up of small towns rather than major cities and rural communities, and was ruled by government representatives rather than kings or feudal lords. It was a nation dominated by a large bourgeois class of merchants, landowners, financiers, and shopkeepers who were able to keep separate spaces for work, which meant a clearer delineation between public and private space. As a result, the average Dutch home housed only four or five people, a decidedly more intimate arrangement than what was common in France or England at the same time. 
By the eighteenth century, the rest of Europe had caught up with the Dutch in the creation of smaller, single-family homes for the bourgeoisie. During this time, Rybczynski writes, "The home acquired a position of social importance that it had never had before, or since. No longer a place of work as it had been in the Middle Ages, the home became a place of leisure." This shift toward private home ownership then triggered a shift away from public life, both beyond and within one's home. No longer did people see their homes as places in which to conduct business or discuss matters of public importance. The home, instead, became merely a symbol of its owner's dispositions and beliefs rather than a place from which he or she expressed them.

This historical association between home ownership and the bourgeoisie is also important because it suggests that home ownership has always been a class marker. Today, Americans who have the means to get a foot in the door through buying a house, and keep it there, have a good chance of parlaying their investments into increasing wealth and a climb up the class ladder-which fits into the American Dream narrative. Recent presidential administrations have encouraged home ownership as a patriotic act that not only empowered American people, but also buoyed the entire economy, and have put into place assistance programs and tax incentives to stimulate home ownership. But buying a home, especially a first home, isn't a straightforward and risk-free endeavor; in fact, as the recent subprime mortgage crisis showed, buyin a home can be a catastrophic undertaking. 
In our case, Alex and I were able to jump through the first-time homebuying hoops rather easily, even though loan requirements in the 1990s were far stricter than they'd become a decade later, because of a combination of financial support from Alex's decidedly middle-class family and future earnings potential based on our college degrees. In a city like Portland, where home prices outpace earnings levels, the road to homeownership can appear to be a long straight line that vanishes in the horizon.

The more legitimate offers of assistance come from nonprofit organizations that help high-risk groups (usually low-income people or racial and ethnic minorities) through home ownership workshops and fairs. People who face an even greater challenge to buying home can sometimes turn to organizations like Habitat for Humanity and community land trusts, but these arrangements are restricted to only the slimmest segment of the general population and often include commitments to assist in the building of the home that can be difficult for applicants to fulfill.

The 2007 Native American Housing to Home Ownership Fair, held in the lobby of one of the Emanuel Hospital buildings in North Portland, featured drumming as entertainment and vouchers for free fry bread tacos. It was a surprisingly cheery site for a fair that was essentially a collection of trade show booths, thanks to high ceilings and glass walls that revealed an adjacent plantfilled atrium. One third of the booths were manned by representatives from banks and mortgage companies, another third by nonprofits that help people 
buy or maintain a home, and the final third by government agencies or tribal authorities.

Participants were encouraged to visit all twenty-eight booths to collect vendor signatures; twelve signatures and they were entered in a raffle for gift certificates from Home Depot or Target, a stereo, a tool set, or even a washer and dryer. Attending one of the classes about affordable rentals or buying a home automatically entered participants in a raffle for a rent-assistance grant or a down-payment assistance grant. The Fair Housing Council handed out crayons and posters for children to color, with the message "I'm Welcome to Choose Where I Live!" on the front and a list of housing rights on the back. The U.S. Department of Housing and Urban Development distributed a thick glossy booklet about its Section 184 Indian Home Loan Guarantee Program, which offers low-down payments, no mortgage insurance, and flexible underwriting. Portland Development Commission advertised its free upcoming workshop about buying fixer-uppers.

One of the loneliest booths at the fair was Northwest Housing Alternatives. Although Kate Kealy, who has a punk-rock streak of pink running through her shoulder-length white-blonde hair, was cheerful and welcoming, she immediately told visitors, "Now, we focus mostly on renting a home-is that something you'd be interested in?" When asked why NHA was even at the home ownership fair, Kealy earnestly explained, "It's very helpful for people to realize that they have a lot of options in finding a place to live-not all of them involve a mortgage." 
Although the fair was held in the midst of the 2007 mortgage foreclosure crisis, few attendants wanted to spend a chunk of their beautiful Saturday talking to Kealy about affordable rentals. Everyone wanted to buy. It's hard to gauge the success of these fairs by looking merely at numbers: According to Sara Libby from Native American Youth and Family Center, the organization that hosted the fair, seventeen people bought or refinanced home as a direct result of the 2006 fair. Considering that only 17 percent of the thirty-one thousand American Indians and Alaskan Natives who live in Portland own their own homes-a far cry from the 65 percent rate of home ownership for all Portlanders-this is hardly success rate to brag about, but according to Libby, it's a huge step in the right direction for an underserved population in a tough housing market.

Amie Diffenauer at ROSE (Revitalize Outer South East) Community Development, which works with low-income home buyers, agrees and says that in $\mathbf{2 0 0 7}$, her organization's Lents Homeownership Initiative brought together some forty community partners to help seventy individuals and families buy homes in the urban development neighborhood in outer southeast Portland. Diffenauer stresses that for ROSE, home ownership, in conjunction with improving public safety and repairing substandard buildings, is the key to revitalizing an entire community.

Especially in recent years, the powerful image of the house as a symbol of the American Dream, alluring tax deductions on mortgage interest, and real estate appreciation have combined to make home ownership irresistible to 
most middle-class Americans. Lenders were more than happy to oblige, betting on infinite growth in the housing market, and, as a result, home ownership rose by almost 10 percent between 1994 and 2005. But by 2007, the much-trumpeted "bubble" began to burst: ARM loans came due bringing with them double-digit interest rates. Across most of the country, communities were saturated with unsellable houses: by the end of 2007, Portland's housing market had an inventory of 8.2 months-the amount of time it would take to sell the houses currently available-which was the highest in recorded history. And behind some of those houses were borrowers in untenable positions of owing more on their homes than they were worth.

A truism about home ownership is that a house can be the best piggy bank a middle-class American can have, thanks primarily to federal subsidization in the form of mortgage interest tax deductions and a historically appreciating real estate market. But as economists are quick to remind us, this kind of savings only works when real estate indeed appreciates and people don't dip into their equities. New Yorker writer James Surowiecki in 2008 wrote that the housing market may not soon recover from the mortgage crisis because these things are not happening: not only are home sales at a nine-year low, but home owners have also greedily tapped into home equity lines of credit, borrowing more than $\$ 600$ billion between 2004 and 2005 (more than ten times the amount from 1994 to 1995) and used the money on personal consumption. Combined with the scary fact that the median down payment for first-time homeowners was 2 percent (compared to 1976, when the average 
homeowner put down 18 percent on their first home), this means that real estate, at least for the near future for a select percentage of the population, is more of a path to ruin than wealth.

Beyond financial risks and successes, the home is still an opportunity for self-invention and self-expression-arguably, two more components of the American Dream. What better way to both tell the world who you are, and to become that storied person in the process, than through your home. Gaston Bachelard, in his seminal book, The Poetics of Space, writes, “A house constitutes a body of images that give mankind proofs or illusions of stability. We are constantly re-imagining its reality: to distinguish all these images would be to describe the soul of the house; it would mean developing a veritable psychology of the house."

This active involvement with the soul of the house, through first acquiring a house and then making it our own, is one part of a circular relationship as the house, then, becomes a kind of proof of who we are. Some homeowners take these communications to another level, using their homes to express their politics, whether through the simple act of placing a candidate's placard in their front yard, or through the more subtle acts of buying expensive but less toxic paint for their living room or disconnecting their downspouts in order to keep city stormwater and sewage systems from overflowing. Mythmaking Americans that we are, we tell others about our actions, whether through the portals of technology that link our lives with friends and strangers both near and far, or in face-to-face exchanges. 
Although it seems paradoxical to think of the private American home as a public space, consider that most Western notions of "public" refer to both physical and psychic spaces. That is, while a public space may clearly be a building or park or other location that welcomes all comers, the notion of being "public" also refers to an action that is intended for viewing, airing, or discussion.

This sense of public as ideological as well as physical is in keeping with German philosopher Jurgen Habermas's theories around the bourgeois public sphere, which "is constituted in every conversation in which private persons come together to form a public." Habermas goes on to describe the public sphere as all-inclusive and not tied to commerce, religion, or government-not terribly different from the Classical Age's forums, described by Alain de Botton in The Architecture of Happiness as spaces "reserved for a superior order of citizens: for political action and the exchange of ideas." These public spheres took the form of coffee houses and salons in Europe in the eighteenth century, anywhere "citizens act as a public when they deal with matters of general interest without being subject to coercion; thus with the guarantee that they may assemble and unite freely, and express and publicize their opinions freely."

For Habermas, then, the space, the people, and the act of conversation comprised "the public," which, in turn, served as a mechanism of democracy because the ideas expressed and actions taken there, when communicated to the other spheres of commerce and government by media, influenced politics 
and society. A modern-day example of this might be the following: A group of Portlanders decide to stop buying vegetables shipped from across the country, and pull up their yards to plant vegetable gardens. A reporter at the Oregonian newspaper writes about this trend. Civic and business leaders read the story and think of ways to support and capitalize on these efforts through policies, goods, and services. Hence, the power of the public as expressed through the actions of private citizens in their homes.

Generally, scholars haven't considered the private home to be a public space, but these scholars haven't experienced life in the twenty-first century, when the Internet has created invisible but pervasive connections between our homes and the outside world. In fact, the traditional props that divide "home" and "work" and "business" are today muddled, with comfortable chairs and reading lights in Barnes and Noble bookstores, coffee and free wi-fi in Umpqua Bank offices, and nap rooms and exercise rooms for the employees of larger companies such as Intel and Microsoft, not to mention break rooms with pingpong tables, couches, and fully stocked kitchens. All the comforts of home just down the hall from your cubicle. As Stewart Brand notes in How Buildings Learn, "Modern society's two great vernacular spaces, the office and the home, seem to be interpenetrating." And in his rationale for creating informal "third spaces" in America where citizens can gather to socialize and converse, sociologist Ray Oldenburg says that people's expectations of the other two spaces-work and home-"have escalated beyond the capacity of those institutions to meet them." But instead of creating "third spaces," Americans 
seem more inclined to adapt their offices and homes to accommodate their complex modern lives.

If such a blurring of lines between spaces is happening anyway, it should happen for noble, not merely profitable ends. Rather than manufacturing privacy in the public sphere-which is similar to the privatization of our homes and the turning inward of our attentions that Oldenburg and other scholars point to as a great post-modern failing-instead of creating a third space, perhaps we should expect that our houses be more than just simple shelter.

In fact, if the arc of Rybczynski's history of home could be traced through the present and into the future, it would seem to loop back to the past, to the bustling common room of the European home in the Middle Ages. Think of the millions of Americans who spend their leisure time on scavenger hunts at area home-parts salvage shops, hunting for specific finials, moldings, or dentils, in order to change their homes into some image of themselves and their ideals. Or the New Urbanists who rally for new communities created in the image of old ones, with garages on alleys at the back and front porches that encourage long visits between neighbors. Or the urban homesteaders who have forsaken pristine green lawns for raised vegetable beds, chickens, and fruit trees. Or the stay-at-home moms who raise their children, advocate their beliefs and lifestyles, and build community through playgroups in each other's homes or on blogs typed during naps and after bedtime. 
We can extrapolate and see how these socially conscious and environmentally friendly actions, which are happening in homes throughout the country, can have a powerful effect on government and business. The home is, again, the largest purchase most Americans will make. While it is generally considered an investment rather than a disposable good, the middleclass home carries in its wake a staggering quantity of accoutrement: couches, tables, beds, appliances, lawn mowers, garden tools, ladders, light fixturesthe list is endless. For this reason, government and corporate America are interested inthe volume of money circulating through middle-class American homes-some savvy consumers know this and are voting with their dollars, opting in or out of lifestyles through the food they feed their families, the clothes they put on their backs, the stuff that they equip themselves with in their daily lives.

In these ways, our homes are already public spheres-sites of conversation and action that collectively influence politics and corporations. Why shouldn't they be purposeful centers of public action and civic concern? Why shouldn't they be the tools middle-class progressives use to build community and affect social change? 
Chapter Two

The Public House

In this brave new world of the American house made public, I struggled at first with the urge to retreat inward. One week after we moved into the house on NE $70^{\text {th }}$ Avenue, Holly and Miles, who owned the 1905 Old Portland next door, said they wanted to throw us a party. This block of neighbors was a very closeknit one, and they wanted to welcome us into the fold. We gratefully accepted, but I fretted about it all week. I had thought this was what I wanted-this kind of house, this kind of community where neighbors have dinner in each other's homes and gossip over fences, loan each other tools and share bumper crops of tomatoes and zucchini. But I worried about how the evening would go, what the neighbors would be like, what our obligations to them would be. But most worrisome to me, who would they think we were based on the snippets of our lives that they observed?

Although he is shier and less sociable than me, Alex grew up on a culde-sac, so he understood how to live in a neighborhood, how to be a part of the place where you live. My family moved often when I was a child-by the time I was seventeen, we'd lived in eight different places, only two of them houses that we owned. I'd moved frequently as an adult, too-the house on $\mathrm{NE} 7 \mathrm{O}^{\text {th }}$ was number eighteen for me. The average American moves 11.7 times in his or her lifetime; just about halfway to the average life expectancy for an American woman, I'd well exceeded the average number of moves. Certainly, this is 
nothing compared to military families who move not only often, but also great distances; my moves have been within and between only two states. Yet, compared to my husband who spent his whole childhood in two houses, I grew up a vagabond. I never had time to get to know a place, much less the people who lived there. Having relationships with neighbors seemed like a big commitment, one I'd only vaguely considered. I spent the first days in our new house rushing from the safety of the car to the safety of the house, watching from behind drawn shades as my new neighbors made small talk on the sidewalk in front of our houses.

We showed up for dinner at exactly 5:05 on the Sunday afternoon of the party, making our way into their back yard where Holly and Miles greeted us. "Sorry, we're late-we got lost," Alex said, as if on cue.

They laughed. I smiled tightly and chuckled, fuming that I hadn't come prepared with a clever remark. I was left to predictably compliment their back yard, which was lovely and in bloom: their lilac was a tree instead of a shrub, and their hollyhocks were six feet tall. Their lawn was thick and green.

We sat in the shade of a mimosa tree, picking at French cheese and Greek olives, talking about moving and unpacking and settling in. Holly said that they'd lived in their house for ten years. When they bought it, it was a wreck, and they'd done most of the improvements themselves: replacing plumbing, refinishing floors, installing irrigation systems. They'd recently paid someone to scrape and paint the exterior of the house but were in the middle of painting the trim themselves. We all looked up at the house and admired the 
butter yellow siding and straight cream-colored lines that peeked from under the eaves and framed the windows and doors.

Ritchie and Kerry, the neighbors to the south, arrived through a gate in the fence between the two back yards, carrying a toddler and a large bowl of pasta salad. As the other neighbors arrived, they exchanged greetings that told of relationships in media res: "Darcy! How's that job going?" "Hey, Joy. I have that CD you loaned me. What'd you think of that other one?" "Ralph, did you get that post moved the other day?" They used so many pronouns with no obvious referents: a clear indicator of intimacy.

Holly eventually called us in to the house because she feared rain was coming. We found seats at the large farmhouse table and passed around platters of salmon, salad, fruit, rice, and bread. All night, the conversation moved swiftly around me: someone loved the new designer on Trading Spaces; someone thought the guy across the street was dealing drugs again; someone was staining a new staircase, which another neighbor had built. The baby cried for more butter on her bread. Someone shooed the dog out from under the table. Someone was going to see Rufus Wainwright at the Aladdin later that evening. Someone asked if the salmon was from the butcher on Killingsworth.

Alex slipped right into the flow, easily telling stories about our first house, our dogs, our jobs. The neighbors listened closely, laughing encouragingly at what was funny, groaning in sympathy at what was not. I sat quietly amid the swirl of talk and laughter. I sipped at my wine, inhaling the 
sharp smell of it trapped in the bowl of the glass. I ran my hand along the heavy wood table, feeling the unevenness of the grain. I looked at the beautiful built-in hutches in the corners of the dining room and admired the elegant leaded glass design of the cabinet doors. I studied the faces of these strangers, trying to find meaning in their still slippery, unfamiliar features. I sat at my place at the center of the long table wondering what it meant that I was here.

When I later thought about my reasons for wanting to live in an urban neighborhood rather than in the suburbs, I realized that my main priority was to be close to work, school, and amenities like public transportation, grocery stores, and restaurants. Being close to other people-having dinner, trading CDs, gossiping over the back fence-was incidental. For me, neither an incentive nor a concern.

So as expected, I was slower than Alex in adjusting to the rhythm of the neighborhood and its rituals of small talk in driveways or while walking the dogs around the block, of waving when we passed each other on the street, of surprise visits from the neighborhood children. Over that first quiet winter of flat, gray days, I found myself missing these daily rituals. I gave in to the appeal of a bustling neighborhood and talked myself into the strange notion of belonging, something that had confused me-my desire for it, my repulsion of it-since I was a child. Like Frank Lloyd Wright's theory that a house should provide opportunities to both nest and perch, I began to understand my need for both private and public lives, for both solitude and community. 
It helped that my innate curiosity about people and social dynamics eventually kicked in. As months of barbecues and holiday parties and impromptu meals went by, I collected dossiers of my neighbors and their homes. And because many of them had lived on the block for years, they also told me stories about previous neighbors: who owned which house, how many kids and pets had lived there, what those owners did to fix up their houses, when they left and why.

I found myself most interested in the story of Joy and Wayne, who had lived in the Craftsman next door but who'd sold it and moved out shortly after Alex and I moved in. Joy was a landscaper and Wayne a contractor, so they'd fixed up the house just so, with beautiful woodwork throughout and complex plantings in the front, back, and side yards. The neighbors called Joy "the night gardener" because, the story goes, in order to avoid the kind of chitchat I'd been fearful of when I first moved in, she tended her plants after dark.

Years prior, Joy wanted to put up a fence between her house and that of her next-door neighbors on the other side who lived in a small, unkempt purple bungalow. Those neighbors did not want a fence. But so long as everything was done to code, there was no need for all parties to agree, so the fence went up-and life for Joy went downhill from there. Her next-door neighbors, one of whom was a loud and brash woman, complained constantly about the fence because they loved to look at at Joy's beautiful garden from their back yard. But the fence went up. It was six feet high and wooden, perfectly serviceable and acceptable, but that was the beginning of a years-long 
feud that involved on good days, scowling across their narrow driveway, and on bad days, spoken exchanges.

Although it had been years since the fence went up, everyone threaded their telling of the story with a trace of bitterness, as if the fence were an affront to the entire neighborhood rather than simply reflective of Joy's reclusive temperament and personality. Knowing I was now the closest thing the neighborhood had to a hermit, I sympathized with Joy and thought of her on days when I came home from a harried day at work wanting some solitary task of pulling weeds in the front beds or sitting on the porch to watch the cars go by. The story of the feud was probably apocryphal, some distilled version of the truth, but it was enough to remind me that, at least in this neighborhood, there was more of an intersection between public and private lives.

But not everyone wants his or her house to be public. Neighborhoods, no matter how close-knit, are not communal housing developments where people share the responsibilities of maintaining common spaces. They aren't even apartment complexes where residents share laundry facilities. But, on the other hand, an urban neighborhood made up of small, one or two-story houses tucked in side-by-side on 5,000 square-foot lots is far different than a suburban neighborhood of horizontal houses sprawling on lots that are two or three times larger. There is an intimacy to a dense urban neighborhood, apparent not only in the architecture of the houses and their placement on the street, but also in logistics of how people move through and inhabit public and private spaces. For example, working in the front yard implies a kind of 
consent to conversation with passersby. So, in a way, choosing to live in an urban neighborhood is acquiescence to living a more public life, one that comes with a particular set of responsibilities to neighbors and strangers alike.

Architect Christopher Alexander addresses some of these public expectations and responsibilities in his seminal book A Pattern Language, which describes how towns, neighborhoods, houses, gardens, and even rooms can be seen as a series of patterns that create what Alexander says is "a coherent picture of an entire region." These patterns describe and explain recurring social or environmental problems, many of which involve the individual's relationship to the community.

For example, pattern 14, "Identifiable Neighborhood," articulates the following problem or need: "People need an identifiable spatial unit to belong to." Using data and theory, Alexander then goes on to describe the need and explain how planners and architects can create such a neighborhood, in this case, by defining neighborhoods that are no more than 300 yards across and with no more than 400 or 500 inhabitants. For this particular pattern, Alexander also recommends that major roads be kept outside of neighborhoods and that residents should be given some degree of autonomy regarding taxation and land use.

Moving from large-scale systems like cities and neighborhoods to details such as lighting and paint, Alexander's book is a fascinating amalgam of practical planning techniques, advice about design, and poetic reflections on the relationship between people and the built environment. The book's 
reverential tone and abstract language can be off-putting to laypeople and critics, but it is inspirational to architects and land-use planners who apply Alexander's theories in their work: he has a loyal following at the University of Oregon, for whom he developed the 1975 The Oregon Experiment, a longrange design plan that has been worked into each of the university's campus plans over the past three decades.

Alexander is seen as one of the most influential architects in the world, primarily because of his belief that people shouldn't rely on experts, such as architects and planners, but should design houses and communities for themselves. This element of group participation, which includes users and designers alike, is rare in large-scale planning processes but is something that resonates in a place like Oregon, where citizens are used to being involved in public decision-making processes. Thinking of a home or neighborhood as a language also makes some sense when considering the interactions and exchanges that we have because of places. In listening to this language and examining the neighborhoods that we live in, and even the very evolution of our houses, we can discern the ways that the house, whether purposefully or incidentally, has come to be both a canvas for and catalyst of broader social changes.

One of the problems that Alexander addresses through his pattern language is the car and its effect on communal life. He expresses disdain for car culture, noting that no more than 9 percent of any development (a school, 
shopping center, or neighborhood) should be dedicated to parking because he believes that with any more, "it is not possible to make an environment fit for human use."

Considering my initial resistance to becoming a good neighbor, it's not surprising that the biggest attraction of the house on $\mathrm{NE} 7 \mathrm{O}^{\text {th }}$ was not its curb appeal but the dilapidated garage in the back corner of the property. The façade was adorned by a trellised miniature rose bush and two shabby wooden birdhouses that dangled by a few rusty nails. The roof was covered with moss. The structure leaned entirely on its north wall, so much so that the double doors gapped badly in their frame. Inside, the building was dark and drafty with no interior walls and a dirt floor. A set of stairs steep as a ship's ladder led to a small loft space upstairs: we could only walk erect under the apex of the roof. The floor was merely plywood laid across rafters and probably only sturdy enough to safely support the weight of a young child.

But the garage had the kind of raw potential that thrilled and inspired us more than any perfectly finished building. I dreamed of fixing the garage up, making it into a workshop space where Alex could build boats downstairs, and a loft upstairs where I could read and write. In less lucid moments, I even imagined tucking a sleeping loft into the upstairs space, under large skylights that could be opened up to let cool evening air seep in. I dreamed of summer parties in the space below, the doors thrown open to the warm night.

Although garages weren't originally designed to accommodate dreams of boat building and summer parties, they were designed for the very 
American dreams of mobility and retreat that cars and the open road could afford. The first garages were makeshift, often modified carriage houses and stables that didn't quite accommodate early automobiles. When Henry Ford invented the car in 1896 in Detroit, he also invented the first garage: He was working out of his neighbor's coal shed when his Quadricycle (a buggy frame on bicycle wheels powered by a 4-hp engine) wouldn't fit out the shed's doors. So he broke through a brick wall instead.

Most early garages were practical and built for many different purposes, to also house horses or even doubling as living quarters for household help. As with most new technologies, those first cars were exotic luxuries, available only to the privileged few, and the garages that followed were also status symbols.

But by the early 1900 s, there were hundreds of thousands of cars on American roads. Companies like Sears Roebuck began selling portable and prefabricated garages that car owners could erect on service alleys behind their houses. Though these structures did their job of storing cars and bulk fuel, they were ephemeral, flimsy buildings. No one knew how permanent a part of American life the automobile would become. After all, the car could have been just another fleeting trend, more technological detritus, like picture phones or 8-track tapes, to be laughed at by future generations.

But future generations did not laugh at the car; they became obsessed with it. One century later, in 2005, the U.S. Department of Transportation reported that there were nearly a quarter billion registered vehicles on the 
nation's highways; of that number 55 percent were passenger cars. Since 1972, there have been more vehicles in the country than individuals licensed to drive them. William Leach in his book Country of Exiles says that by the 1990 , there were twenty-four-million miles of paved roads in the United States and declared America the "empire of movement."

The car was perhaps one of the largest blows to cohesive American neighborhoods and communities, which had once been designed as interdependent, fairly close-knit networks of work, home, commerce, and leisure. Neighbors relied on each other and nearby businesses. With the car, residential communities could sprawl and be farther from services such as schools and shops. The post-World War II convergence of the interstate highway system, cheap raw materials, and the GI Bill also played roles in the birth of the suburbs, but Americans' love of cars only hastened the outward march away from urban cores and created a clear public-versus-private divide between work and home.

The American home reflected this change as well. By the 1940s, the garage had gone from being a detached, peripheral structure to being an integral part of a home's architecture. Instead of bungalows and Craftsman houses that included garages placed well away from the house proper for fear that car fuel would catch fire, mid-century suburban ranches integrated garages onto the main footprint of the floor plan, often with access through the kitchen. Women's magazine articles from this time period laud the virtues of 
the attached garage, describing the ease with which housewives could carry their groceries from car to kitchen.

Consequently, almost every American house constructed since the 1950s included a garage. In fact, these newer houses seemed to be designed with the car rather than the community in mind. Garages were given prominent positions at the fronts of houses-so-called "snout houses"-giving the impression that houses are temples to automobiles. When the garage doors are open in these developments, the view from the street is no better: "It's as if a succession of enormous, messy closets had been opened to public inspection," writes Philip Langdon, in his book A Better Place to Live. This placement also distanced the house and its residents from the rest of the neighborhood; in many, the front doors are difficult to find, as if hidden to ensure a family's privacy, which was vastly different from more traditional houses that go to great lengths to welcome visitors from the street with a front pathway, porch, and clearly visible front door.

These developments, featuring grid upon grid of the same house in different colors, were intended to satisfy a dream of prosperity-albeit of a homogeneous sort-for all. Although picture perfect and seemingly readymade for a middle-class family's lifestyle, many theorists and researchers now believe that the suburbs are alienating and isolating to residents, because houses were located far from public gathering places. It was, as advertisements promised, possible to move from house to garage to car to work and back again without having a single personal encounter with a stranger. 
Additionally, for many Americans, garages have come to represent not mobility, but immobility. Synonymous with stuff, garages today seem to hold not only cars, but also a household's overflow: athletic equipment, seasonal gear, tools, lawn furniture, extra furniture and clothes. Despite my most vivid imaginings, our garage on $\mathrm{NE} 7 \mathrm{O}^{\text {th }}$, five years after we moved in, was no different: rather than doors thrown open to the warm night, full of people and food and music, our garage was full of tools, bikes, gardening equipment, firewood, and unused furniture. The garage, rather than freeing us to the open road and outside world, weighed us down and kept us turned inward, obligated to our myriad possessions that, at the end of the day, weren't important enough to keep in the house proper, but not trivial enough for us to give away.

According to the American Institute of Architects, more than 50 percent of Americans live in the much-maligned suburbs. One of the most vocal opponents of suburban life is Harvard University political scientist Robert Putnam, whose 1995 book Bowling Alone is a bible for modern-day community revitalization advocates. Putnam says that the suburbs have resulted in overly privatized social lives for many Americans: "With increased use of automobiles, the life of the sidewalk and the front yard has largely disappeared, and the social intercourse that used to be the main characteristic of urban life has vanished... There are few places as desolate and lonely as a suburban street on a hot afternoon."

Putnam also says that the homogeneity of the suburbs is also damaging 
to democracy because a lack of disagreements regarding political and social interests reduces the kinds of conflicts that draw citizens into the public sphere. Bill Bishop's 2008 book The Big Sort supports Putnam's damning of homogeneity, but they both seem to miss the larger point: that not everyone wants to participate in such a public square and build close relationships with their neighbors and fellow citizens.

In the 1980s, New Urbanist architects and planners began leading a charge to move the garage to the back of the house, where it was before the postwar housing boom, saying that neighborhoods lose their sense of community when garages and cars take precedence. "No architect is skillful enough to make human life project itself on the façade of a house when sixty percent of it is given over to garage doors," write architects Andres Duany and Elizabeth Plater-Zyberk.

Inspired in the 1980 s by the theories of architects Leon Krier and Christopher Alexander and based in large part on pre-World War II housing development patterns, New Urbanism espouses mixed-use, pedestrianfriendly planning as a better option over suburban sprawl. New Urbanist architects and developers believe that the antidote to suburban life is smalltown life built around "Main Street," when democracy flourished, and that this life can be created whole cloth through good planning and design.

Although some New Urbanist developments are urban infill projects, many are, like suburbs, set on large tracts of land outside of urban cores. Unlike suburbs, however, New Urbanist communities are compact designs 
built around town squares that include retail, business, green spaces, and public transportation integrated with homes on walkable grids. New Urbanist homes can be either traditional or modern in design, but nearly all put garages on the backs of houses to encourage more contact between neighbors. In 2008, there were more than two hundred New Urbanist developments across the country.

The handful in the Portland area include the successful Fairview Village and Orenco Station, which are just outside the urban core but linked in by high-speed rail. The newest development sits on the site of a former lowincome housing development in North Portland. The New Columbia is a federal HOPE VI (Housing Opportunities for People Everywhere) housing project that not only includes the public green spaces, retail, and school, but also mixed-income housing, from low-income apartments managed by the Housing Authority of Portland to market-rate single-family homes. The jury is still out on whether this New Urbanist project is a success or not, but New Urbanist developments in the Portland area do well in large part because of the region's Urban Growth Boundary, which was established in 1980 to concentrate urban growth within the boundary and preserve farm and forest land outside the boundary. As a result, developers have found creative ways to house the city's growing population and residents have learned to value the benefits of high-density life.

However, across the rest of the country, Americans aren't buying into the New Urbanists' campaign. The first and perhaps most famous New 
Urbanist development, Seaside, Florida, is today no more than a collection of timeshares and vacation homes. Other New Urbanist-inspired HOPE VI projects sit partially occupied or even uncompleted, urban wastelands in communities around the country. In a 2005 New York Times article about why New Urbanist homes don't sell quickly, experts say that the projects are more popular as concepts to architects and planners, adding that most Americans are reluctant to give up their cars. (This was before the steep increase in gas prices in 2008; the Congress of New Urbanism says there's since been greater interest in walkable or bikable communities of late.) One Orlando, Florida, realtor quoted in the Times article explains that some of her clients specifically don't want a "sugar house": a home where a neighbor can easily stop in to borrow sugar.

Winifred Gallagher, author of House Thinking, says that architects are fully aware that houses must function as both private and public spaces. Inspired by Wright's theory of nest and perch, Seattle architect Grant Hildebrand describes this need as prospect-refuge. In an interview in Salon magazine, Gallagher says, "The whole problem of being human, the whole challenge of being human, is to find the balance between our autonomy and independence and our need for other people and our interactions with other people." The urban home and neighborhood are ideal places where humans can do both.

For instance, when I think of the countless conversations I've had with neighbors on the street-some about real estate, some about current events, 
some about the personal details of our lives-I realize that these conversations help to build up the cornerstones of community lore, of our shared lives together as they intersect in the public spaces of our neighborhood.

When residents think about, critique, and reflect upon the appearances of other homes in a neighborhood, they're not only gathering personal information about each neighbor, they're also determining each household's willingness to be a part of the neighborhood's established culture. In the quasidemocratic way of unspoken but shared language, there is something political and public when one neighbor pulls up his or her yard and plants vegetables while the others plant wide expanses of perfectly green front lawns.

Although these unspoken neighborhood rules aren't codified, as they are in condominiums and gated communities, they can be just as powerful. Regardless of the specifics of a neighborhood's rules, there are more subtle hierarchies and social dynamics that ultimately have bearing in the workings of a neighborhood.

In an episode of the radio program This American Life, geographer Denis Wood described unusual maps he made of his own neighborhood that give a visual sense of these neighborhood dynamics. Some of Wood's maps show the location of infrastructure, such as manhole covers and streetlights. He says his map of traffic signs, which are by and large for people who don't live in the neighborhood, shows a density of where strangers move through community.

Other maps reflect the neighborhood's culture, such as those depicting 
which porches have jack o'lanterns at Halloween and which residences are regularly mentioned in the neighborhood newsletter. Wood says that these two maps show a strong correlation, which in a sense determine both a central core and the power structure of the neighborhood. "I imagine that the people who are going to be movers and shakers in the neighborhood pick homes that are in important locations or are architecturally significant or historically significant," Wood says. He adds that his maps cumulatively show the structural knowledge of how a neighborhood works. "[These maps] are what it is to live in the neighborhood," he says. "The neighborhood is experienced as a collection of patterns of light and sound and smell and taste and communication with others." Like Alexander, Wood sees the neighborhood as a kind of language through which people communicate about difficult things, such as power and class.

New Urbanists point to the porch as a key piece to the public/private puzzle of the house; as such, many New Urbanist developments include a front porch or stoop. Architect Christopher Alexander specifically points to the porch as a private public area that exists in the public sphere of the neighborhood: "If people cannot walk out from the building onto balconies and terraces which look toward the outdoor space around the building, then neither they themselves nor the people outside have any medium which helps them feel the building and the larger public world are intertwined."

Philip Langdon in his book A Better Place to Live says that before World War II almost every house had a porch, but since then the outdoor life 
of the home and its inhabitants has shifted from the front of the house and the street to the back. "Private areas behind the houses have been upgraded, while public areas facing the streets and sidewalks have surrendered much of their social importance," he writes.

If the loss of the porch can be read as an indicator of how houses (and the people who live in and design them) have turned away from the public street, toward what have they turned? As Langdon suggests, perhaps to the back yard, with gourmet barbecue grills, swimming pools, hot tubs, $\$ 10,000$ swing sets, and even trampolines. And looking inward, the evolution of the kitchen also shows the struggle between the dual roles of the house.

During the Middle Ages in Europe, when homes had few rooms but many people moving through them, the kitchen was located centrally in the living space because it contained the hearth, which served as a cooking and heating source for centuries. Rybczynski notes that only the wealthiest European homes included private rooms in the seventeenth century, so until then the kitchen couldn't be hidden away. And Akiko Busch, in Geography of Home, describes the kitchen in Europe as neatly kept as a public room.

The Industrial Revolution brought changes to kitchens in Europe and the United States in the form of stoves that were fired with coal and wood, and by the mid-180os, most American homes relished the fuel efficiency of the new appliances. However, these cast-iron or porcelain stoves required the use of dirty fuels, so the kitchen through the Victorian age was increasingly seen as no more than a service area from which bad smells emanated that needed to 
be closed off from the rest of the house. Even with the advent of gas and electricity in the nineteenth and twentieth centuries, the kitchen remained as a room kept under wraps. The architecture of houses from this periodVictorians, Craftsmen, and Bungalows-all show the value of the kitchen as central though closed off from the rest of the house.

It wasn't until the mid-19oos, in large part because of even more efficient appliances and the work of home economists who took kitchens seriously as domestic laboratories that the kitchen began moving to the center of the house again, and, in many cases, became open to the public rather than hidden away. Ranch houses were designed with half walls linking the kitchen to the dining room, which was often open to the living room, thus giving guests a clear sight line through the entire house upon first arrival. Suddenly, even the "dirty" kitchen was visible to all visitors, and the house could be read like an open book.

Until I lived in the house on NE $70^{\text {th }}$, I had never considered that a private home had the potential for being public. But that's because I'd never seen my dwelling in any way but as a setting for my own life. I'd never thought of the way that my house and things in it might be part of a larger work: a block, a neighborhood, a district, a city, a region. I'd never considered that my thoughts and beliefs were communicated, whether I wanted them to be or not, through the house I lived in. But, of course, I was wrong: there were ways that I used my house to show solidarity or dissent, through something as obvious as 
signs I posted in my yard or something as subtle as the color I chose to paint the siding. The very fact that I lived in the neighborhoods that I lived in told people volumes about who I was, or aspired to be. My homes had always been public spaces at some minimal default level: ratcheting it up a notch or two would have to be my choice.

I grew to love living in a close-knit neighborhood, even when the unspoken codes and rules touched off the rebel in me. Having people nearby to gossip with or keep an eye on things while we were out of town turned out to be only the smallest benefits of knowing our neighbors well. Over the years, more unpredictable and valuable ones followed. When we had to put one of our dogs down, the neighbors brought flowers and food. During an ice storm that shut the city down for a few days, the neighbors pooled the contents of their cupboards and refrigerators, then slowly slipped and skated to our house for a "cabin fever" potluck. Once, Alex got it in his head to poach a whole fish and went door-to-door looking for a fish-poaching pan, to no avail. But that year on his birthday, guess what one of the neighbors gave him? If ever we needed anything, the only thing I ever had to do was open my front door and go house to house: someone would drop everything to help me. These were the things that made our little house-and our little lives-bigger than the sum of its parts.

None of this is to say that our collective lives were without conflict. Although in most cases, open disagreements were deftly avoided, they did happen, and they were not just about things like fences and paint colors. Once 
I was involved in a back yard conversation with a neighbor from two doors over whose daughter was about to enter kindergarten at the neighborhood school. Not for the first time, she told me how worried she was about the latest redistricting that would bring kids from north of our neighborhood, which had perhaps a lower socioeconomic demographic than ours, into the school. In particular, this neighbor, a former grade school teacher herself, worried that "Hispanic gangs" would infiltrate the grade school, bringing not only an element of violence but bilingualism.

The first few times she described her worries, I shrugged them off; this neighbor had a tendency to make random racial and ethnic generalizations that, as a person of color, made me wince but had never motivated me to go into "teachable moment" mode, primarily because those prior exchanges had always been within a larger group setting. That day in the back yard, however, it was just the two of us with no one else in earshot, so I mustered up my courage and remarked that the likelihood of "Hispanic gangs" in a Portland grade school seemed small. Then I quickly noted that our neighborhood also included large eastern European and southeast Asian communities, so that issues involving nonnative speakers would likely be old hat for the school.

I like to imagine that my words were as measured as they appear on this page, but I know they were not. I'm sure my face was red and my tone clipped and annoyed; I remember her quickly changing the subject, so we never really had the kind of conversation that Habermas or Oldenburg or Putnam might have wanted us to have, the kind that broadens people's minds and affects 
policy changes. And I can't say it was a conflict I was glad to have in the relative serenity of my back yard on a beautiful summer day. But it felt like a truer example of what we mean when we say "community building" and provided a kind of ballast to the otherwise fairly light and sublime exchanges I had with my neighbors, the ones that only years earlier had me hiding in the shadows of my house. 
Chapter Three

The Home Laboratory

Within two weeks of moving into the house on NE $70^{\text {th }}$, Alex cut a hole in the wall between the living room and a bedroom and put in a set of French doors, which nearly doubled our living space. Because of the noise, he waited until I was out one evening before breaking through the lath and plaster, and I arrived home later that night to a cloud of dust, the sight of wires dangling from open walls, and a new life of plastic tarps and face masks.

The bungalow wasn't technically a fixer. It was absolutely habitable, according to the bank appraiser and to us. We slept in the roughly finished attic for years before completely remodeling it, though the ceiling was lined with three different sizes of acoustic tiles and the subfloors threw off brown latex paint chips that clung to the soles of our bare feet. The rest of the house was fine: any other homeowners might have merely repainted the main living rooms and perhaps had the kitchen cabinets refaced, and then called it good.

But for Alex and me, the house was a perfect laboratory, a place to try out new ideas and designs-what would the walls look like in bright orange? What if we carved out space for a bathroom upstairs and installed skylights that let eastern light in? What if we added an exterior door at the back of the house where the nook was? Perhaps it's easier to feel inspired by home remodeling projects that address creative longings rather than necessities. 
When we first looked at the bungalow, the living room and adjoining dining room seemed impossibly small. Brad chalked it up to the owners' clutter and over-large furnishings, but even several weeks later, when we walked through the empty place for the first time after getting the keys, those front rooms felt stingy and tight. In a typical sellers-market kind of buyers' remorse, that first walk-through was incredibly bittersweet: It was later in the evening and the previous owners had left the place dusty and dank, the smell of basement permeated all the rooms of the main floor. We fumbled in doorways, searching for light switches, but once lit, the deserted rooms seemed too yellow and faded in the glow of cheap light fixtures. The house, which had loomed large in memories garnered from only two brief visits, was disappointing: a smaller, sadder replica of itself, shrunken and deflated.

The main problem was the floor plan-there was no drama, no surprise, no central gathering place that could accommodate more than a handful of visitors at a time. We knew that would have to be the first thing to change. Many of these modest, 1920 s bungalows were designed the same way: a front door that opened directly into the living room, which was divided from the dining room by half walls or a broad archway, with a kitchen through a single door beyond. Also included on the first levels of these small homes were two bedrooms, a bathroom, and a steep set of stairs that led to an attic, which by the end of the twentieth century, more often than not, had been finished to provide more space. In her book Bungalow Nation, Diane Maddex notes that "a bungalow's universal characteristic is that it is no bigger than it needs to 
be."

Increasingly, middle-class Americans are discovering that though they have character and soul, old houses like bungalows don't always adapt to modern lifestyles. My Portland friends and I frequently chide each other for complaining about how our houses seem barely large enough for our small families of three or four, because we know that much larger families were raised in them, with three or four children to a room. While the size of the American family has shrunk decade by decade, its activity level and, subsequently, need for privacy has inversely grown-and quiet space for oneself is a tough commodity in a traditional two-bedroom bungalow that must accommodate a modern family's comings and goings.

But even for homeowners who creatively use nooks and corners of other larger rooms, including the less-finished spaces of attic and basement, it's undeniable that our activities today come with a lot of stuff: closets crammed with jackets for every season and equipment for every recreational activity, kitchens full of gadgets and small appliances, basements and garages piled high with unused furniture and boxes of mementos. No longer do our activities swirl mainly within the walls of our homes-sewing, cooking, canning, cleaning, reading to one another, working together in support of the domestic life of the family. As Stewart Brand writes in his book How Buildings Learn, "Economically, the home has been completely transformed in a hundred years from a place of production to a place of consumption."

Marjorie Garber notes that it's easy to be judgmental about materialism 
and consumption, and pass them off as displays of status. "But take away the sense of invective here," she writes, "and you will be left with a different kind of 'reality': things, commodities, objects, consumable goods, are not only possessions but a kind of language. They are, like it or not, the way we communicate with each other, with ourselves, and with the world." Although it may be of little comfort when complaining about the lack of a dedicated playroom or TV room in our 1,400-square-foot bungalows, at some level, these demands make sense in that we want our homes to both meet our daily needs and tell the story of who we are.

But rather than building a new house that does all of this in the suburbs, many middle-class Americans like me are turning to major renovations of traditional houses in the urban core. With their sense of history and soul, bungalows can ease the anxious, guilty minds of intellectuals who feel that through renovation, they can become a part of a house's history, while actively shaping its future.

Architect Ellen Fortin often helps her clients redesign their traditional homes to fit their lifestyles. But, she says, "it's funny how homes are no longer really remodeled for how people really live, but instead, they're designed around how people want to live." One of Fortin's clients asked that the kitchen be designed around making cookies during the holidays-with a large double oven and several feet of granite counter space-even though she barely cooked the rest of the year. "I thought it was crazy," Fortin says, of the expense her 
client was willing to incur for an annual task. "But I did get cookies at Christmas, and they were great."

Fortin and her husband, who is also an architect, have extensively remodeled their own 1922 bungalow since buying it fourteen years ago: moving their attic stairs to improve the rise and run and refinishing the upstairs by adding a dormer to accommodate a second bath and two goodsized bedrooms for their family of four. Like us, Fortin and her family sacrificed a downstairs bedroom to create more living space, breaking the room open to the kitchen on one side and adding exterior doors that lead to a small, lush back yard on another to create a cozy family room. In the basement, the couple has carved out storage, laundry, and hang-out space for their two school-aged boys, the latter complete with a pull-out bed that slides through the wall behind it and fits into a platform that doubles as the bottom of a closet.

Fortin calls herself a modernist who's made the best out of her traditional house-one of the plethora available in good eastside school districts within minutes of downtown. She describes her crazy dreams of Lucite walls and concrete floors, but then points to the admittedly traditionallooking archway that separates the newly remodeled kitchen and family room. "We thought about opening this up completely, but then it wouldn't have looked right," she says. "It's important to respect the traditions of a house, even as you make it more modern." 
Although we weren't aiming for drastic renovations like Fortin and her family with our NE $70^{\text {th }}$ bungalow, Alex and I, by breaking through a wall in our living room, not only opened up the floor plan and added to our living space: we had also started down a path of spending most of our disposable income on serious remodeling projects. And we weren't alone. According to the Joint Center for Housing Studies at Harvard University, Americans spent $\$ 280$ billion on home remodeling projects in 2005-and most of these Americans were middle- to upper-middle class, white homeowners between the ages of thirty-five and fifty. So, when Alex and I pushed a lumber cart through Home Depot on an early Saturday morning, most of the people we passed in those wide aisles were a lot like us.

The JCHS studies use the more broadly popular terms "Baby Boomer" (for those born between the mid-1940s and mid-1960s) and "Generation X" (for those born between the mid-1960s to the early 1980s) when analyzing figures, which show three interesting trends. First, there is a strong correlation between home improvement and age, with data showing that "average expenditures per household increase steadily through peak spending years, which are between the ages of 35 and 45. After that, remodeling decreases slowly as household heads reach their 50 , before dropping off more significantly as they reach 60 s and 70 ."

Second, although baby boomers clearly dominated the home improvement market not only in size and dollars, they also changed the way Americans viewed their homes, which then put new demands on the 
remodeling industry. A JCHS study notes, "When the members of this generation began to turn thirty-five, predictions were rife that they would act more conservatively and start to save more of their income, as their parents had. However, the boomers remained true to their free-spending, unconventional ways, helping to propel the housing market and the remodeling industry to the heights it enjoys today."

The third interesting remodeling trend is that members of Generation X tend to live in much older homes: the average age of Gen X homes is thirtyone, which is ten years older than the home boomers owned when they were in their thirties. The JCHS study notes that this is in large part a result of the country's aging housing stock and that, logically, these older homes require more maintenance and remodeling work. "Owners of older homes also tend to upgrade and modernize the appearance and structure of the home."

These studies not only give us a glimpse at the culture of remodeling in America, they also provide the home improvement industry with some pretty valuable market research. And companies have capitalized. By the end of 2007, Home Depot, which first opened in Atlanta, Georgia, in 1979, was the world's largest home improvement retailer and country's second largest retailer overall, with 2,234 stores in the U.S. and $\$ 17.7$ billion in revenue. Interestingly, 1979 also marked the birth of the television remodeling show, This Old House, which led the way for the hundreds of similar TV programs that followed, including an entire station dedicated to home improvement and design programming: HGTV, which launched in 1995. By 
2000, the TV show Trading Spaces introduced the new genre of reality TV home improvement in which families, with the help of designers and contractors, remodel rooms in each other's houses.

This Old House also broke trail on the newsstands, creating a new home improvement subgenre of shelter magazines with a periodical of the same name, introduced in 1995. Many publishers followed suit, creating specialized remodeling magazines that were sometimes only offshoots of already popular periodicals. The entire shelter magazine business-which, according to Marjorie Garber, has the sole goal of selling desire-has exploded since then: An American Society of Magazine Editors report says that 192 interior design and decoration titles were available in 2006 , more than double the number available only ten years earlier, and architecture magazines grew from 119 in 1996 to 145 in 2006.

The most obvious factors that account for this surge of interest in and consumption of home improvement-related products and media are rising incomes of home owners and falling prices of both real estate and home remodeling and decorating materials. In her book The Substance of Style, Virginia Postrel notes that after correcting for inflation, "the median U.S. household income has more than doubled since 1955, and jumped 29 percent since 1975 -even as families have shrunk, giving them yet more income per person. We can afford more aesthetic goods, from faucet sets to sweater seats, because we can afford more of everything. ... Thanks in large measure to wives 
with professional salaries, upper-income families have seen their incomes rise even faster."

This was certainly true for Alex and me. As our income grew, we invested more and more of our money in our house. While we could only afford to buy used furniture and complete the most basic of home improvement projects (i.e., painting and yard work) with our first house, we spent a lot more on the house on NE $70^{\text {th }}$. Over the years, we bought new couches, rugs, artwork, and appliances, and dropped thousands of dollars on remodeling and home improvement projects. We saved money by doing almost all of the work ourselves, except for hiring a friend's son to paint the exterior and slipping some cash to contractors who were working on a neighbor's home when we needed some sheetrocking done in the kitchen. But still, a lot of cash went out of our bank account and into that 5,000 square-foot city lot. Some of the expenses were typical old house maintenance, like upgrading the gas furnace and electrical, but a lot of it was to make our house look attractive and reflect our tastes.

Postrel says that people have always decorated their homes, but particularly in the last decade or so, "Furnishings once reserved for rich aficionados are now the stuff of middle-class life. In the early 1990s, when Pottery Barn launched its interiors-oriented catalog, American homeowners could not buy a wrought-iron curtain rod without hiring an interior designer. ... Now such once-exotic offerings can be found in discount stores.” She accounts for this affordability with new product sources and improved 
distribution: “Granite countertops and marble floors aren’t more common just because we're richer. Inexpensive, high-quality stone slabs now come from China and India, while portable edging machines developed in the midnineties let fabricators open new businesses with minimal investment. As a result, says an industry watcher, natural stone is 'no longer a material just for the upper class."

But despite the simple math of middle-class homeowners being able to afford to improve their homes and decorate them well, what is the psychology behind this seeming obsession with home renovation and remodeling? For Alex and me, the feeling of accomplishment was a natural high, and the way our projects impressed our visitors was an added benefit. In showing off our work, we were telling our community who we were, and the praise and admiration we received in return worked like positive reinforcement does with children and dogs: we turned around and did another project, and another, until we became known as creative, handy homeowners. We're not alone on this: I've been through countless "middle-class home tours," impromptu walks through friends' home in which they point out the work they've done, or the work they're going to do, on their houses.

By casting our home improvement projects as narratives-complete with details, conflicts, and resolutions-we tap into the American love of mythmaking, with the homeowner as protagonist. Stewart Brand explains that not everyone considers altering a home a positive endeavor. "Adaptive use is the destiny of most buildings, but the subject is not taught in architectural 
schools," Brand writes. "Any kind of remodeling skills are avoided in the schools because they seem so unheroic, and the prospect of remodeling or rehabilitation happening later to one's new building is even more taboo."

Yet the average DIY home remodeler, whether doing something as small as putting up a light fixture or as large as adding a second story to a house, considers such efforts heroic. It's hard to deny the swelling pride of accomplishment and the measure of satisfaction that comes from laying hands on a house, to wake up in a completely remodeled attic bedroom and think, "We did this. Before there was only subfloor and mismatched acoustic tile, but now, there are bamboo floors and skylights and fresh paint and new trim." It's a smaller version of American exceptionalism-Manifest Destiny and Horatio Alger rolled together and played out in a middle-class home.

Marjorie Garber has a more romantic, or perhaps codependent, view of the phenomenon as a courtship between homeowner and house. "This mutual and constant courtship, this ongoing relationship, imperfectly commodified and imperfectly consummated, is what produces both the anxiety and the enjoyment of owning a home," she writes. "The keynote of much home design today is not character, not values, but desire. And desire, by its very nature, cannot be satisfied. It points always onward, toward the next redecoration, the next renovation, the next house."

This desire might be for beauty and aesthetics, or for a process-the cycle of earning and receiving admiration and respect. But in an essay for New York Times Magazine, writer Robert Sullivan describes Americans' obsession 
with home improvement as a secular religion: “People don't just tinker around anymore," he writes, "they seem to believe that their homes should be the purest expression of themselves." Perhaps, then, the desire that manifests in home ownership is the wish to be visible and known: the house as proxy for self.

But Randy Gragg, the editor of Portland Spaces magazine, thinks that there may be a darker side to the remodeling craze: "Home is a place where people have control. I think the world seems very distant and difficult to influence." In transforming our homes, then, we maintain some power over even a tiny corner of the world, but I suspect that part of our need for control is internal, as well. Whether we do the work ourselves or hire contractors, those of us with money to spend on our houses fully understand that just down the street, someone is living in a hovel and can just barely afford heat and food. That world, too, is difficult to influence and improve, no matter how many meals we serve at the soup kitchen or how much money we give to charities during the holiday season.

Perhaps at some level, then, we need to justify the feathering of our nests-an act, which, at the end of the day, is undeniable proof of our participation in consumer culture. So we tell ourselves, and our communities, that we spend money in virtuous ways: by improving and extending the life of an old house rather than buying a new one, by investing in craftspeople and local economies, and by matching our expenses with our time, labor, and good intentions, thus, imbuing our homes with soul. Narratives of heroism and self- 
righteousness make it easier to sleep at night in our down-lined, 300-threadcount covered beds.

Some strange combination of all these things-guilt and narcissism, fear and desire-is what brought Alex and me to the gaping hole in the bungalow on $\mathrm{NE} 70^{\text {th }}$. Although we weren't newbies to home improvement projects-in our first house, we'd designed and built a brick patio with a pergola and fire pit, and Alex had poured a concrete countertop in the kitchen-we'd never cut through a wall before or installed a set of double prehung doors, but between Alex's confidence and my naivete, anything seemed possible. Because we were broke-we'd blown all of our cash on this house and between Alex's new job and my part-time gig plus grad school, there wouldn't be a lot of extra money coming in each month-hiring contractors to make improvements was out of the question. And that's how we became do-it-yourselfers.

Optimism and romanticism, with at least a small helping of naivete and a streak of independence, are the building blocks of do-it-yourself culture. This plays out in home improvement in a big way. In a 2004 survey conducted by the National Association of the Remodeling Industry, 44 percent of respondents had undertaken do-it-yourself projects, most of these for smaller, less expensive jobs. The main reason for doing the work themselves was enjoyment, though keeping expenses low was also a motivating factor. In $2000, \$ 58,484,000,000$ spent on DIY projects, more than 25 percent of what was spent on professional projects. 
Stewart Brand, author of How Buildings Learn, understands the temptation to modify houses. "Site-built [platform-frame houses are] rebuildable, much more than factory-made housing, even mobile homes," he writes. "Platform frame-2-by-4 wood stud walls raised a floor at a time-is an amateur medium. You can build or rebuild an entire house with a power saw and a hammer. ... For reasons unknown-perhaps our frontier historyAmericans revel in doing major home projects themselves, and so we stick with forms that give us that freedom."

True, there's a kind of god-complex at work here. But this is not a new phenomenon. Winifred Gallagher, in her book House Thinking, uses Thomas Jefferson and his beloved house, Monticello, as an example: "As is true of more of us than might admit it, Jefferson was obsessed with his home-in his case, from the age of twenty-five until his death at eighty-three-and never saw it as quite finished. Like many a do-it-yourselfer, he declared, 'Architecture is my delight and putting up, and pulling down, one of my favorite amusements.”

Of course, not everyone falls for the romance of the DIY home remodeling project. Writer Robert Sullivan describes the culture of DIY home improvement as an "obsessive labor that passes itself off as leisure." Later in the essay, as he crouches before a broken dishwasher, he has a realization: "For two years I'd been working on this house, and there was still no end in sight. It had become my Vietnam." 
However, Portlanders are optimists to the core, plagued by more than just a little guilt and guided by a strong sense of social responsibility. As a result, the city has become a vortex for DIY practitioners, from those in the design/build industry, to craftspeople like knitters and woodworkers, to indie musicians. Some say it comes from being a Western state, a place where cowboys and trailblazers are still considered heroes rather than traitors or instigators. Others claim that the burgeoning creative class of young artists is drawn to mid-sized progressive cities like Portland, hoping to become big fish in small ponds. Still others say that the state's landmark legislations that made beaches public, bottles returnable, and farmland worth saving also make locally owned, independent business successful. In a city like Portland, it's better to be small, shoestring, and politically left than it is to be corporate anything.

Translated into the home remodeling industry, companies that specialize in alternative, recycled, salvaged, or used building materials, like EcoHaus, Rejuvenation, Hippo Hardware, and the Rebuilding Center, are nationally renown. The same folks we'd see first thing on Saturday morning at Home Depot, we'd probably see later in the afternoon ogling bathtubs at Rejuvenation, digging for molding at Hippo, or sifting through doorknobs at the Rebuilding Center.

Brian Sheets is someone we likely would have run into at Home Depot or Hippo, and probably would have struck up a conversation with if we were all admiring the same pedestal sink. But we first heard about him as "the guy 
who's fixing up the big pink house up the street," and then met him and his wife through a neighbor.

The Sheets have since moved on to a 1912 bungalow in Southeast Portland, which started as a major remodel but turned into a whole house gut. The house was in disrepair because of being poorly remodeled and maintained, so it was offered by its elderly tenant for a shockingly low price, which in turn generated the kind of frenzied bidding war that was common at the turn of the decade but more of a rarity in the cooling 2008 market. The Sheets's savvy realtor suggested the couple write the owner a heartfelt letter and include the Christmas photo of their young children along with their cash offer-a tactic that worked even though their bid wasn't the highest on the table.

Once the Sheets took ownership of the house and began poking around, they realized that the job was bigger than they'd anticipated, and Brian founds himself looking at months of work, from moving a stairwell, to pulling asbestos siding, to redoing all the systems. Although it had been in the hands of the same family for fifty years, many of the original details had been stripped during a remodel, except for the coveted box beam ceilings in the living room and wood floors throughout, both of which Brian will retain throughout the months-long project.

Because the house is a near gut job, Sheets decided to explore having his remodeled house certified through the U.S. Green Building Council LEED (Leadership in Energy and Environmental Design) program. The family 
anticipates selling the home for a profit in the coming years and believes that LEED certification will be attractive to Portlander buyers. But besides wanting to distinguish the house when the time comes to sell, Sheets and his wife have in the past couple of years caught the eco-bug, which, in Portland, is hard to avoid. They've watched King Corn and they buy organic produce from farmers markets. They frequent thrift stores or make the things they need. For them, remodeling their fourth house using green practices is the next natural thing to do.

There are different levels of LEED ratings depending on the number of points a homebuilder or remodeler accumulates across the various categories, from water and energy efficiency, to landscaping and materials. Some points are given for things the homeowner can't control, such as distance from "basic community resources" (e.g., bank, pharmacy, post office, restaurant). Others are given for the installation of Energy Star appliances and a high-efficiency HVAC system. Although points aren't removed for less sustainable practices, there are some prerequisites that must be met, such as not using invasive plants or only using FSC-certified woods.

Sheets says that the LEED for Home process is best-suited to new construction because in most cases older homes have to be retrofitted to gain points. For example, he says that instead of getting points for building energyefficient storm windows for the original windows of this house, he'd have to tear the old windows out and install new energy-efficient windows, which is a huge expense that would ultimately only earn him three points. (To get 
baseline certification, he'd need to earn forty-five points total.) At this point, Sheets is trying to devise a rainwater-harvesting system and gray water-reuse system, as well as high-efficiency plumbing fixtures that could earn him a total of eight points. He found two 250-gallon plastic drums for cheap on Craigslist that sit in wait on the east side of the house.

The City of Portland's Office of Sustainable Development tries to encourage builders and remodelers to use green practices by hosting an annual green home tour for which people buy tickets and get a map of some twenty green houses across the city that are open for viewing on a given day. Because the tour sells out each year, the houses are crammed full of curious people who run their hands over smooth Paperstone countertops, ask experts about the logistics of a living roof, and gawk at a formidable three-stage 7,500 gallon rainwater system that provides a home with drinking water as well as gray water. In one North Portland home open on the tour, the builder proudly posted on a bedroom wall the checklist that earned his house the minimum seventy-five points required for a LEED-H Gold rating; a crowd of six or seven people huddled at the wall intently reading the list.

My confidence that we would have met the Sheets even if a neighbor hadn't introduced us stems from two things: the nature of Portland as a small city where everyone is within two or three degrees of separation from each other and the fact that Portlanders like to chat about the work they do on their houses. For DIY home improvers, talking about our projects have become the 
topic of conversations at parties and the crux of water cooler talk at the office. We trade stories, advice, and information, meanwhile building our investments in each other's lives.

But because residential houses, like all architecture, are public in that their exteriors and landscaping are on view to anyone, home remodeling projects, especially the large-scale ones, are also public acts to be shared with complete strangers. Passersby on a residential street are as likely to slow down and rubberneck a major home improvement project as they are a major traffic accident. These engagements are admittedly more narcissistic than altruistic, motivated by our curiosity in what other people are doing compared to what we are doing-like reading home and garden magazines but firsthand. But though our observations of these public projects have limited value to the remodeler, they have infinite value to other observers, usually neighbors, who use the projects as fodder for gossip and small talk.

One afternoon in late spring of 2006, I noticed an estate sale sign up at a beautiful old but neglected Craftsman on $64^{\text {th }}$ and Alameda about ten blocks away from my house. I raced home to tell Alex, but he'd already seen it. We made plans to visit the house that coming weekend. The rest of the week, our street was abuzz with neighbors anticipating a peek inside. On Friday, the first day of the sale, Alex was at work, but I couldn't wait. I dragged a visiting friend over to the house, which was already swarming with bargain hunters and gawkers. 
The house was, as we expected, in terrible condition with at least a couple of months remodeling work left to do. The place was piled to the ceiling with stuff. One room was full of violins, guitars, and other stringed instruments. Another was full of books. Yet another was full of golf clubs. The kitchen was littered with gadgets and dishes. The basement was full of tools and appliances.

As we made our way up the grand open staircase to the second and then the third floors, despite the disrepair, I felt as if I were in a museum. How would it be to live in such a stately house? The women running the sale were relatives of the man who'd lived there. They said he'd lived alone for years and couldn't keep up with the maintenance on the place. He didn't have running water for the last few years, so used the huge buckets in the upstairs bathroom: he'd catch rain water then cart the buckets upstairs and use the water to flush the toilet. No one in the family wanted the house, so they'd sold it to a couple of developers for cash. At this, my heart sank a little, but because this was such an unusual house, I felt sure that they would do a decent job if they wanted to sell it for what would likely be a huge mark up.

When work started on the house, Alex and I changed our normal route home, forgoing quick-and-dirty Sandy Boulevard for the stop signs and wide curves of residential Alameda Drive. At least a couple of times a week, we commuted to work separately: he on his bike, I in the station wagon. At the dinner table, we'd report what we'd glimpsed of the house remodel: workers were power-washing the weathered siding, a backhoe was removing trees and 
brush from the south side of the property. Every time I drove by, I saw another neighbor standing on the curb watching the workmen.

By the time the house was put up for sale for $\$ 689,000$, we could barely bring ourselves to go to the open house. We'd seen enough to know that they'd cut some corners (they replaced the original porch columns with square ones that were too small for the scale of the house and did a quick painting job). Although they'd remodeled the kitchen, added a bathroom to the master suite upstairs, replaced the heating, plumbing, and electrical systems, they didn't spend any extra money on the details-the stuff that makes old house lovers swoon and inspired architect Mies van der Rohe's famous quote, "God is in the details." We toured the house with wrinkled noses then compared notes with our neighbors about the failings of the remodel. It proved to be a topic that sustained our conversations at gatherings and on the street well into winter.

This kind of house talk among middle-class homeowners isn't merely sport: It's a mechanism for establishing a neighborhood's culture.

Metaphorically, it's the common thread that stitches our varied lives together at a common point in place and time. Although my neighbors and I only had the vaguest sense of each other's lives beyond our homes-jobs, family histories, lives before $\mathrm{NE} 70^{\text {th }}$-we bonded over home improvement projects and real estate. These acts and events became public spaces--places where we all felt free to linger and ideas we all felt free to critique.

Our decision to sacrifice a ground-floor bedroom in order to get more living space was at some level an acknowledgement of the public nature of our 
lives. It was a way of expressing some of our values: that we were creative problem solvers, that we did work with our own two hands, that we wanted more space for visitors. But though we each have a modernist streak in us, hence our desire to open up the floor plan even more, we also wanted the doors to look like a part of the house, not separate from it. Alex found a strip of original crown molding in the basement that would help visually link the doorframe to the rest of the room. We installed doors that were similar to the multi-paned front door, complete with period glass doorknobs.

But the most interesting result of this first project was that it made our house public in more ways than we expected. Besides giving our visitors more space in which to spend time with us, the project announced our arrival to the neighbors. The day after the sound of the saw rang through the early summer evening, Kerry stopped in to see what all the noise was about. She joked that our quick bolt out of the gates was making the rest of the neighbors-all do-ityourselfers to one degree or another-look like slackers. Wayne, the notoriously shy finish carpenter who lived next door, stopped in to introduce himself and offer support. Ralph, a former contractor and now ER nurse who lived across the street, came by because he'd seen Alex hauling debris out to the curb, that telltale dust caught in his hair and on his skin. A gruff, taciturn man, he and Alex immediately bonded over the best and worst ways to rewire a room.

In the days that followed, we left our curtains and doors open as we primed and painted the trim and frame. We painted our living room an 
unfortunate shade of orange that, from the street, seemed to make the room glow and pulse and give off heat. Although our neighbors were politely optimistic about the color, they also made recommendations for how to tone it down using a wash, which worked to give the color more texture and make it seem warm rather than hot. It was the first of many home improvement projects in the years that followed, and we shared nearly all of them with our neighbors: asking their opinions while we planned, asking their advice and assistance while we worked, and when the project was done, we always invited them to view the finished product. Although at the outset we hadn't anticipated this kind of elaborate relationship between our home, our neighbors, and ourselves, we soon realized that if we allowed it, our house could be an open book and the best way possible to tell our community who we were and of what we were made. 


\section{Chapter Four}

\section{Mommy Power}

Within a few years of moving into the neighborhood on NE $70^{\text {th }}$ Avenue, Alex and I took the next natural step as middle-class homeowners: we became parents. By the time our daughter, Stella, was born in the fall of 2004, we'd grown into our roles as DIY remodelers and good neighbors-keeping the house and yard maintained; making home improvements that added value to our home and, therefore, our neighbors' homes; offering tools, equipment, and advice to neighbors as requested; keeping secrets or sharing information as appropriate.

If not for our community of friends and neighbors, Stella wouldn't have had a place to sleep. In the summer before she was born, as I grew larger and more unwieldy, Alex tore the poorly finished attic space apart and framed out bedrooms. Strong-backed friends and neighbors carried heavy sheets of Drywall up the steep stairs and helped sheetrock the rooms, three holding the pieces in place while one nailed them in. Alex spent the next several days taping and sanding, and taping and sanding, emerging from the attic stairwell covered in fine dust except where his goggles and facemask had been. In August, we painted the little room off of our bedroom a sunny yellow and furnished it with a crib, rocker, and dresser that doubled as a changing table. Stella spent the first two years of her life tucked under the eaves in that little space, only steps away from us. 
After she was born, a steady stream of visitors came through our front door for two months, bringing with them casseroles of hot food, bags of handme-down supplies, words of advice and encouragement, and offers to help around the house. I like to think that Alex and I weren't the only ones buoyed by these gifts, these visits that broke up long days at home and made our transition into our new roles easier, but that Stella also felt the warm embrace of the world beyond our little house.

And although we couldn't have articulated it at the time, Alex and I realized in those early days that the stakes were suddenly higher: we now had a witness to our lives, someone who would be right there alongside us for at least the next two decades, watching and learning from every move we made. How would we continue to show her what it meant to be at home in the world when we were only just beginning to understand how to be so ourselves?

We intuitively knew that we should keep doing what we'd been doing and surround her with our efforts-successes, failures, and draws. To do otherwise, to pretend that we had it all figured out, would have been artifice and not something we could have sustained for long. So we continued to remodel our house, to build relationships with the people in our daily lives, and to figure out how these actions and connections played out in the larger world. We, like many new parents, felt the immense burden to be not just good parents, but good people.

This changed our domestic lives in a couple of big ways. Although we'd for years been eco-conscious people who recycled and had subscriptions to 
community-supported agriculture farms, after Stella was born, we found ourselves, in the age of progress and convenience, moving backward: away from formula and bottle-feeding to breastfeeding, away from Huggies and Pampers to cloth diapers and wraps, away from store-bought jars of baby food to homemade baby food. Although nearly every mother I knew was nursing (over the past decade, Oregon has consistently had one of the highest rates of mothers who breastfeed), only a handful were using cloth diapers and making their own baby food.

Yet, by the end of Stella's first year, Alex and I could daily be found either in the basement washing diapers or in the kitchen steaming peas and carrots until they were soft and then milling them into thick purees that we spooned into ice cube trays and put in the freezer for later use. For years, we'd had a farm share for organic vegetables and had also been regular visitors to the local farmers markets that were held four or five days a week within the city limits. But now we had new purpose for these bundles and bushels of produce. Stella devoured everything we presented her, from mashed sweet potatoes to pureed spinach. As she got older, she happily waved snippets of soft green beans and stalks of steamed broccoli in her chubby fingers before devouring them, too.

These were our first attempts to model good citizenship to our child, though she was too young to notice. We'd read startling facts of how disposable diapers, besides being very costly to produce, were piling up in landfills. And we wanted her to eat whole foods grown by people who worked 
on the farms surrounding the city where we lived, not processed foods manufactured hundreds of miles away. Although both of these debates continue unresolved-the water used for cloth diapers versus the resources used for disposable, the nostalgia and expense of small-scale farming versus the food security and resource concerns of agribusiness-at some point, we had to make a decision and support, through our money and our time, what we thought was best way to live the world. And so we did.

And in the same way that moving into the neighborhood on $\mathrm{NE} 7 \mathrm{O}^{\text {th }}$ forced me to look outward, to become a more public person, becoming a mother also made me look outward-but this time, I did so more purposefully. This turned out to be difficult. I'd always been comfortable with my own company and had strong tendencies toward reclusiveness, which showed in my awkward adjustment to living in a close-knit neighborhood. I thought I'd adapt well to the solitude of staying home with a young child, but, ultimately, the monotony of nursing, diapering, rocking, and soothing an infant got to me. I cried when Alex came home in the afternoons, not only out of relief for the company of an adult but also, in dismay of having another person in the house (which by then was beginning to feel small and claustrophobic) who had even the mildest expectations of me.

So, I ventured out, leaving my home to learn how to be a mother. I went to mommy-and-baby support groups held in community recreation rooms, where weary women rocked and bounced their children, while complaining about lack of sleep and worrying about the color of their babies' poop. I went 
to the local library story time and learned lullabies and songs. I went to the zoo and to the toddler rooms of the local science and children's museums, where Stella crawled around with other children, putting things in her mouth and building up her immune system.

Ultimately, I couldn't quell my skepticism that friendships could be built around something as pedestrian as having a child, so I didn't develop any new relationships. Instead, my relationships with women I'd known before we had children deepened. We found a balance between talking about the challenges of raising our children and the concerns and interests we had in the world at large. It wasn't until Stella was older that I discovered a network of other women who, like me, were trying to figure out how to be socially conscious and politically active parents.

Women have long used their homes as social and political centers, whether by hosting monthly book groups, baking cookies for school fundraisers in their kitchens, or organizing grassroots campaigns on local issues. But increasingly, there's a decidedly green tint to Portland-area mommy gatherings. Many of these women, no matter how much they do or don't work outside of the home, are embracing lost domestic practices, like knitting and food preservation, and a surprising number are doing it in order to steer their families toward more sustainable lifestyles and reduce their reliance on mass-produced items. Some call it the new Cult of Domesticity, others link it to third wave feminism or do-it-yourself culture, or the latest version of the original Arts and Crafts movement, which also rejected mass 
production. But in Portland, especially, there is a visible surge of interest among mothers in everything from vegetable gardening and chicken raising, to thrift shopping and sewing, that reflect efforts to live more sustainable lifestyles.

Combine this phenomenon with the fact that what counts for community has also changed. Although mommy gatherings were once solely face-to-face affairs with women gathered in each other's living rooms, kitchens, front porches, or back yards, the Internet has given women the chance to create powerful, virtual communities organized around shared interests. Websites like iVillage and Strollerderby, or Momocrats and Blogher, have become go-to places for parents (most of them mothers), not just to get advice and information, but also share their interests and concerns with other readers.

The Internet has also opened the home up to the outside worlds of work and commerce, giving parents the chance to work completely or partly from home and also to buy groceries, diapers, clothes, and other household supplies. Whether through dedicated home offices for those who have their own businesses or work remotely, or from a desk in the corner of the living room where blogs are written and shopping is done between meals or after the children are asleep, the house has become a place of commerce, community building, support, and activism for many modern-day parents.

Rebecca Andersson is one of many Portland moms who is using her home and the Internet to raise her children in socially responsible and 
politically progressive ways. For Andersson, these efforts show up most obviously on her front porch. One of the most distinctive features of her 1913 Craftsman house, the porch runs the entire width of the house and is a generous five or six feet deep. Every other weekend, it serves as a makeshift store, supporting some three thousand pounds of beans, rice, baking goods, and produce, not to mention the people who mill about searching for their purchases.

Andersson is the founder of Portland Green Parenting, a community of 150 families that share similar eco-friendly and voluntary simplicity values for raising their children. Aside from an active online forum, where members offer support about parenting challenges, share political and current events news, and trade advice about where to find cheap kid raingear, Andersson's home in Portland's Richmond neighborhood is also a place where members convene for workshops and pick up groceries and eco-friendly goods.

Several times a months, large delivery trucks turn off of Portland's bustling Hawthorne Boulevard-peppered for thirty blocks with coffee shops, pet supply stores, restaurants offering every kind of ethnic food, and independent clothing and household supply stores-onto Andersson's long, quiet, residential block and stop in front of her house. Her home is a drop point for Azure Standard bulk foods from Dufur, Organically Grown Company produce from Clackamas, and Thundering Hooves grass-fed meats from Canby. Although the bulk foods and produce wait on her porch for a couple of days until families from around the area can come to retrieve them, Andersson 
says thankfully the frozen meat, typically $\$ 1,000$ worth per month, is delivered instead to a pallet in front of her house by a truck-"It's like an ice cream truck," she says, "but it's full of meat and [the driver] doesn't play a little song." Families order their items-whether pounds of organic sugar and canning jars, a bin of organic local fruit, or a half a lamb-directly from the companies and then pick them up at Andersson's house. For each delivery, Andersson asks a few volunteers to help her sort, and sometimes weigh and divide, the purchases.

Andersson and her boyfriend were drawn to Portland from Los Angeles in mid-2007 because of rumors of the area's livability, so the family found a house (the likes of which she says they could never have afforded in southern California) and moved north at the end of summer 2007. Andersson, who has an eleven-year-old child from a previous relationship, wanted to do things differently with her younger daughter: She eschewed a hospital delivery for a birthing center, was intrigued by attachment parenting and extended breastfeeding, and wanted to live in more sustainable ways. But Andersson says she wanted to find a community that she could learn and get support from as she explored these new lifestyles, which she describes as alternative and contentious. "It's draining to argue," she says. "I didn't want to be judged. I just wanted to surround myself with supportive people.” Although she'd always been active in online communities, she craved face-to-face interactions: “A relationship with my laptop wasn't satisfying." 
So she turned again to the Internet, but this time, she set up an account on Meetup.com, a social networking tool that helps people arrange gatherings based on interest. The first incarnation of PGP was hit-and-miss, with Andersson organizing get-togethers at her house to which sometimes no one showed up. But after a few months, a core group formed and once members started pooling their resources to buy food in bulk from Azure, the group really took off. In early 2008, Andersson asked her boyfriend, a website developer, to create a site specifically for PGP, which allowed her to set up a virtual store where she now sells things like baby slings, green household cleaners, and sustainable bamboo dishware, as well as food.

Andersson doesn't make much of a living using her house as a store for PGP families. She makes a small profit off of produce and retail goods sales by buying items at wholesale and rounding the prices up a bit. Thundering Hooves offers her a 5 percent credit for every month's sales, but she makes nothing off of Azure foods. And she's torn about profiting from people who have become her friends: "I'm putting in all this work that deserves compensation. But I don't want to make money or push products, even though they're good products." And she's quick to point out that she's met her original goal of making friends and building community.

She says that PGP has also helped her come to terms with her decision to withdraw from her doctoral program in anthropology at the University of California at Irvine to become a stay-at-home mother. Like many women, Andersson says that she really struggled with her identity once she became a 
mother, but particularly so after her second daughter was born. "The messages that I have are very contradictory," she says. "On the one hand, I recognize [that motherhood] is a really important job. But on the other hand it's devalued. You don't really have power as a stay at home mom in public. People don't value it the same as a CEO or executive." As founder and organizer of PGP, she says it's nice to be able to say that not only is she a stay at home mom, she's also a small business owner.

She says that through PGP's sustainability workshops that teach people how to make their own cheese or raise their own urban chickens (the family has five chickens that roam their back yard, pillage their garden, and come running for snacks when they see Andersson at the back door), as well as through its food buying groups, which support local companies and farmers rather than franchise grocery stores, she has some influence and power. "We're making consumer choices and voting with our dollars," she says. "But it's still hard. I don't feel 100 percent at ease.”

I similarly felt torn between my new role as a mother and my old role as a career woman. On a daily basis, it seemed, I vacillated between wanting to stay home with Stella as she discovered the world, inch by inch, and wanting to be back among adults who told amusing stories and had interesting insights about art, culture, and politics. Like Andersson, I struggled with the notion that "real" work happened in the outside world, and what happened within the walls of a home was something else. 
Portland writer Daveena Tauber says generations of women have been unable to reframe the value of domestic work because such labor is still primarily understood in emotional terms: "Resistance to the idea of wages for housework or even tax-based support for working parents is rooted in our discomfort with the idea of assigning monetary value to what we see as an essentially private and emotional labor-a labor of love."

But as a part-time stay-at-home mom, I began seeing a world that had previously been invisible to me: during weekday mornings, neighborhood and city streets were full of moms and their young children. They were out on walks, they were frolicking in parks, they were taking up all the best spots in coffee shops, they were filling the parking lots of the zoo. There seemed to be something noble in foregoing income and career aspirations in order to raise your children yourself. It also seemed clearly tied to the green parenting movement that was afoot in the city, with childrearing as yet another lost domestic skill.

I found that on the days I was home, I really craved, like Andersson, the company of like-minded parents who were trying to figure out how to raise thoughtful, compassionate children-and how to be better people themselves. During naptime or during the rare moments when Stella was content to amuse herself, I stumbled upon a surprising source of information and support: community-based women's websites, which are tied with political websites as the fastest growing online categories, according to ComScore Media Metrix, an Internet measurement company. These sites reached more than 85 million 
visitors-nearly all of them women-in May 2008, which is 42 percent more than last year.

But it was the blogosphere that was a particular revelation to me: millions of people equipped with no more than Internet access and a computer were keeping diaries of their daily lives and posting them for the world to read. Technorati, a search engine that tracks blogs, reported in August 2008 that there were some 112.8 million blogs on the Internet, with 175,000 new blogs being added each day on every subject imaginable, from fan sites dedicated to particular celebrities to political sites that analyzed each day's top news stories. Parenting blogs, most of which were written by women, with their built-in domestic heroines and adventures and conversational tones, were immediately appealing to me-and to millions of other women who frequented the sites each day.

Mommy blogs showcased a world of witty, smart women who both regaled and decried motherhood, who openly admitted their mistakes and proudly crowed their accomplishments. Never a good journal keeper myself but always a voyeur, I spent hours wandering from site to site, engrossed in other women's struggles to be good parents.

But the blogs that intrigued me the most were the ones that seemed to show how the concerns of the home could affect change in the world. Here were moms, many of them who stayed home to care for their children at least part time, who weren't content to just shuttle their children from activity to 
activity. And many of them started out, like me, not fully understanding the Internet's community-building capacities.

Rebecca Kelley, cofounder of the website and blog Green Baby Guide, was such an Internet neophyte when she and her friend, Joy Hatch, started the site in 2007 that she told her webmaster it would be neat if they could use imbedded links rather than URLs on their site-a rudimentary and de rigueur offering in this interactive age.

"Joy and I don't really know how the technical stuff works," says Kelley, "and neither of us is interested in learning."

Hatch, a seventh-grade teacher who lives in Eugene, Oregon, first approached her old college friend Kelley, a Portland-based college writing teacher, about the idea of creating a green baby book in February 2007. The two found their friendship rekindled and intensified when they became new mothers and realized they shared a desire to be eco-conscious, frugal parents. Neither knew many other young mothers who used cloth diapers, made their own baby food, and trolled Craigslist for used baby furniture and accoutrement. They hoped to pool their research and share it with other mothers who had similar green values.

They quickly attracted an agent, who told them that they should immediately develop a website and build a platform of readers, which would make it easier for them to the successfully pitch their book to publishers. Neither had spent much time in online communities and blogs, so they 
enlisted the pro bono assistance of Kelley's cousin, who ran a website development business in California, and on December 22, 2007, logged their first post about eco-friendly alternatives to Christmas gift-wrapping paper.

As with most blogs, Green Baby Guide initially only attracted a few visitors a day, but after employing some basic Internet marketing tactics on the advice of their agent and webmaster, the site's monthly traffic began doubling every month. By summer of 2008, the site averaged 350 hits a day and 10,000 unique visitors a month-enough to land Hatch and Kelley a book deal with the Stewart Tabori \& Chang, publishers of The Lazy Environmentalist and other successful green books.

Kelley, who works as an adjunct professor at a Portland arts and crafts college, says that for her, the community-building component of blogging wasn't much of a motivation. She acknowledges that the Internet has been a boon for moms to connect with each other about parenting issues and concerns, but she was more interested in sharing her thrifty and eco-conscious tips and values. Yet, she's reluctant to call herself an environmentalist or to say that what she's doing is political-“I don't write my congressman or letters to the editor," says Kelley. "I just vote."

She admits that others see her as an environmentalist, primarily because she's been a vegetarian on principle for more than twenty years and as a teenager was an avid recycler in her hometown of Carson City, Nevada, long before the task was as easy as dragging a bin out to the curb. "I'm not really altruistic; I just want people to do things my way.” But she acknowledges that 
having a website and blog touting green, frugal lifestyles for parents "is as political as I've gotten in my life because [before now] I haven't had a platform for about the way I think things should be done."

Like Andersson and me, Kelley says that having a child inspired her to become a better person. She uses the Internet to create community, air views, and educate herself from within the walls of their own homes. Increasingly, bloggers like Kelley are drawing large numbers of readers, over whom they have considerable influence. A recent study by BlogHer, a website that helps publicize female bloggers, found that thirty-six million women write and read blogs each week. Another figure says that 64 percent of the audience who read BlogHer blogs have bought something on the recommendations of the blogger. In fact, the San Francisco Chronicle noted that more than half of the blog readers and writers surveyed said that the considered blogs to be reliable sources of information for everything from consumer purchases to analysis of the presidential race.

At this summer's BlogHer conference, one thousand women showed up in San Francisco to hear how they were the most coveted market in the country: women who control their households' finances, are Internet savvy, and who have PayPal accounts and credit cards. In an article about the conference, Gina Garrubbo, executive vice president of BlogHer, was quoted as saying, "There are millions of dollars to be made," said. "Online media is taking away from traditional media and blogging is a new medium. Mommy blogging is one of the biggest and most influential sectors." BlogHer has 
reported that between 2007 and 2008, the number of blogs registered on their site has grown from 180 to $2,200-$ which is a lot of women being read by a lot of women.

Despite these numbers and the relative parity among internet usersaccording to the Pew Internet and American Life Project 14 percent of men and 11 percent of women blog-many say that mainstream media doesn't take female bloggers seriously. For example, a conference for progressive political bloggers was scheduled for the same weekend at BlogHer and websites and news publications that compile "best of" lists for bloggers include only a handful of women.

Part of this is probably steeped in the predominantly personal nature of women's blogs. For example, one of the most well-known and well-paid mommy bloggers is Heather Armstrong, a Salt Lake City mom whose blog Dooce is read by one million people each month-a number high enough to earn her $\$ 40,000$ a month in advertising revenue. Armstrong can't be described as a political or green blogger; her blogs consists primarily of irreverent observations about marriage and parenthood, as well as her struggles with clinical depression and leaving the Mormon Church. Because of her success, her husband quit his job to manage her website.

But Armstrong is a lottery winner in a field where few bloggers make a living; some sell advertising, but BBC News says that of those who do, the average income is $\$ 100$ a month. And in a country where money has considerable sway in changing governmental policies and corporate actions, 
it's hard to see how mothers who use the Internet can hope to affect much social and political change. But the sheer numbers of women who read other women's blogs, most of which deal with the triumphs and challenges of domesticity, might mean that where second and third-wave feminism failed to help women's contributions be seen as valuable, mommy bloggers are succeeding. I wouldn't be surprised if Dooce became required reading in feminist lit classes.

And this one-two punch-women returning, literally and figuratively, to the home and domestic crafts, plus the appeal of this group to big business-is beginning to have a noticeable effect in mainstream consumer culture as well. For example, why are the shelves of super stores like Target and Wal-Mart are now lined with products like Clorox Green Bleach, organic pepperoni sticks, and wooden toys made not in China but in the USA? Considering the fact that products for the home represent a huge chunk of consumer sales even in a flagging economy and that women are the primary shoppers for their households, marketers seem to be paying attention to what's going on with women like Andersson and Kelley, who've matched their politics with technology, to wield some influence among other women. 


\section{Chapter Five}

Green Acres in the City

The power of home and community in the world at large can best be seen in the yards and on the sidewalks of urban neighborhoods like $\mathrm{NE} 7 \mathrm{O}^{\text {th }}$ Avenue, where my neighbors and I discussed the world around us. There was a lot to talk about: A tiny Cape Cod around the corner had been stripped down to the studs and was being rebuilt into a sleek modern creation out of Dwell magazine, something most neighbors thought hideous. A couple of people in the neighborhood had pulled up their front lawns and parking strips to plant vegetables, which most of the people on our block tolerated, but thought odd. A bungalow down the street had been repainted into what many considered a garish shade of orange-"What were they thinking? Was there a clearance sale on ugly paint?" The rental house across the street had fallen into disrepair with peeling asbestos shingles and a dangling screen door that clanged during windstorms, a sound that so aggravated one neighbor she threatened to go over there and rip it off the hinges herself.

Our own front yard wasn't much to speak of. It wasn't offensive, but it wasn't a statement either. It was simply nondescript-modest, unambitious gardens of perennials on either side of a narrow concrete pathway, which was lined with ancient lavender shrubs that by fall lost their heady scent and color to resemble gray, gnarled fingers. It seemed to be symbolic of our continued ambivalence over individual interests and community concerns, over the 
house as both private and public space. Shouldn't we have made more of an effort to match the lush gardens and facades of our neighbors' homes? Shouldn't we have gone to great lengths to offer our visitors a grand entrance to our humble, but charming home?

Instead, we invested our time and money in our back yard. When friends and family first visited us in the house on $\mathrm{NE} 70^{\text {th }}$, they made their way through the rooms, politely commenting on the house's quaintness and brightness, complimenting us on our choice of paint colors. But when they peered through the back door at the yard, their jaws dropped. Even before we carved out garden rooms and built a pergola that was later covered by grape vines, honeysuckle, and passionflower, the yard was a surprise: a lush green paradise in an urban neighborhood, fronted by a plain dime-a-dozen bungalow.

The back yard in home ownership lore is a place of privacy and contemplation. It is the stage for our leisure life, whether pool parties and BBQs with family and friends, or play dates on enormous and expensive wooden swing sets and trampolines. It is a place of retreat where we spend quiet moments gardening and reading and napping. For us, our yard was no different.

Although it's hard to deny the appeal of the quintessential American back yard, scholars deride the expense and wastefulness of the well-shorn lawn (a recent New Yorker article says that Americans spend an estimated forty million dollars on grass each year) or point to the back yard as a symbol of 
selfish and capitalist leisure. Ray Oldenburg describes the back yard as a symbol of Americans' declining investment in public spaces, citing modernday, middle-class household staples, such as barbecue grills and televisions, as flying in the face of "earlier shared forms of entertainment and diversion brought people together." These diversions, such as public pools and parks, he says, "were good for the community but not good for the economy. The worst student of arithmetic could understand that more money would be spent in a nation where every household tries to own what a community once provided for all.”

In small ways, our neighborhood on $\mathrm{NE} 7 \mathrm{O}^{\text {th }}$ bucked that trend. Our second summer there, we added three more gates between adjoining back yards (there was one already there between two of the properties that belonged to the longest-tenured residents), linking five of our properties together. The arrangement made it easy not only for neighbors to spend time together or help each other with projects, it also made socialization between frolicking dogs and children spontaneous. But the gates also created a kind of quasiprivate space away from the rest of the neighborhood, akin to a private park accessible only to members. It also raised some questions about rules for such a public/private space. For example, was it okay to traipse through one neighbor's yard to visit another? When a neighbor had once invited you to use the gate to snip a sprig of rosemary from her enormous shrub, was that a standing offer? While hardly political, these considerations are good examples of how the gates complicated our previous understanding of public and private 
spaces. We negotiated them carefully, adding them to our mental neighborhood rulebook.

In Portland, lawns are political in and of themselves. But instead of red versus blue, the colors involved are brown versus green, particularly after summer finally takes hold and rain showers are few and far between. Almost every time Alex's mom visits Portland in the summer, she comments as we walk through the neighborhood, "People here don't water, do they?" She lives in a suburb of Minneapolis where all the neighbors have large, green unfenced yards, most maintained by landscaping companies that aren't shy about using the chemicals and water that lawns need to stay green. Before that, she lived in a suburb of Chicago, and before that, a suburb of Denver. In every neighborhood she's lived in, lawns look green and lush, no matter that many of these lawns, especially the ones in high and dry Denver, shouldn't look that way.

People in Portland do water, and you can tell who they are because their lawns are unnaturally bright green even in August. But that kelly-green lawn or too much lawn, both so valued in mainstream suburban America, is anathema to the city's progressive bourgeoisie. The local alternative weekly even runs an annual feature called "Water Hogs," listing area homes that have the highest water bills, under the reasonable assumption that most of that water is going toward landscaping. In Portland, having no lawn, a brown lawn, or an alternalawn-a woody/herby turf mix developed by the Oregon State 
Extension Service that requires little or no mowing and watering-is akin to making a political statement.

In a 2008 New Yorker article about America's anti-lawn movement, Elizabeth Kolbert describes lawns as steeped in politics and class. She says that these ideological conflicts are yet more carryovers of the suburban dream and quotes Abraham Levitt, developer of America's first and most famous suburb, as writing, "A fine carpet of green grass stamps the inhabitants as good neighbors, as desirable citizens." (Levittowners agreed to mow their lawns once a week between April 15 and November 15.) Kolbert explains that such a statement flies in the face of the fact that turf is native to almost nowhere in the United States. Despite this, the United States in covered with enough lawn to cover an area the size of New York state and that it would take two hundred million gallons of water per person, per day, to keep well irrigated and pristinely green.

But besides the crop's overdependence on water, environmentalists and anti-lawn proponents, beginning with Rachel Carson, have long protested the use of highly toxic chemicals that keep turf green, suggesting that lawns instead be allowed to go wild or, better yet, be dug up and replaced with beds planted with food. Kolbert writes, "Instead of demonstrating that a homeowner cared about his neighbors, a trim and tidy stretch of turf showed that he didn't." She notes that given the shift in Americans' awareness of the cost, in dollars and resources, of lawn upkeep, the anti-lawn movement may finally be getting some traction. 
In Portland and other cities with progressive bourgeoisie, this traction sometimes takes the form of urban homesteading: the use of city yards to grow food and to raise chickens for eggs and goats for milk. The practices of supporting local farmers and companies, as well as voluntary simplicity and eating seasonally, tend to go hand in hand with the urban homesteading lifestyle.

Urban homesteading is a twist on Oldenburg's arithmetic critiquing the money Americans spend on leisure equipment that keeps them turned inward toward the home rather than outward toward the community. In this case, urban homesteaders invest in their homes rather than in the public and commercial spheres like grocery stores, using capital to set up sustainable systems like farming, food preservation, and keeping back yard farm animals, creating what might be called microeconomies within their home. Unlike previous "back to the land" movements that saw young people heading to far rural reaches, the current movement is happening in cities.

The most famous urban homesteaders in America are the Dervaes family, Jules Dervaes and three grown children who live on a one-fifth acre urban lot in Pasadena, California, where they harvest more than six thousand pounds of fruits and vegetables each year. They sell what they don't eat themselves to local restaurants and catering companies, and use most of their profits to invest in energy-efficient technologies, including solar panels and energy-efficient appliances. They use a solar oven to cook food on hot days and 
process their own biodiesel to fuel their vehicle. Because of these efforts, their energy bill is sometimes as small as $\$ 12$ per month.

Since 2001, the family has been writing about their efforts to reduce their carbon footprint on their website Path to Freedom. Their goal is to inspire other urbanites to follow their lead and encourage self-sufficiency in the city. The blog draws more than thirty-five thousand monthly visitors, and the general website receives more than six million hits per month. Major media, including the New York Times and $C N N$, featured the family's work in 2008.

Critics argue that these self-reliant microeconomies work against the implied interdependent nature of a city, creating a different but equally damaging kind of privatization of the public sphere. Instead of supporting grocers or farmers by buying their goods, for example, urban homesteaders not only opt out of agribusiness, they opt out of local economies as well. But some urban homesteaders say that their lifestyle choices more strongly connect them to both local and global communities.

Sarah Gilbert, the closest thing Portland has to a celebrity blogger, dragged her skeptical family into urban homesteading in 2007. They live in a sweet little bungalow that's in need of some repair: the porch sags badly and the whole thing could use a new coat of paint. It's set on a larger than average, fruit-tree covered lot on one of the major north-south avenues in southeast 
Portland, close to shops, bus stops, and bike routes: in other words, the perfect setting for an urban homestead.

A native Portlander, Gilbert says she's long been interested in food and cooking, and has worked in restaurants since high school. "I've always been a label reader," she says. "And high fructose corn syrup and partially hydrogenated vegetable oil has always made me mad. But it's only been recently that I've started getting passionate about it."

She says the first inklings that led her down the path of growing and making her own food set in during the spring of 2007 when she was in her second trimester with her youngest son. "I had to a garden," she says. A mother of three young sons, Gilbert adds, "It was this crazy nesting thing. I hear the more children you have, the greater the nesting instinct hits you in the second trimester." So she took a week of vacation (she works full time at home as a financial blogger for AOL) and dug up her yard to put in large vegetable beds. "I was out there with a big belly, digging up blackberry vines," she says, laughing.

Gilbert got her first chickens at the same time, and it was such an impulse buy that the fowl were free-ranging by default because Gilbert and her husband didn't build a coop. "It was this thing that overtook me," she says. "I was unable to ignore the urge to garden and get chickens."

By summer, however, Gilbert and her family found themselves down to one chicken, a timid bantam named Twitter (in homage to the social networking tool that she and millions of other bloggers use to report on the 
details of their daily lives, 140 characters at a time) who stayed behind when the two others decided to wander away from their unfenced territory last year. In the days after the hens ran away, Gilbert logged onto a Portland forum for urban chickens and spied a "found" notice posted by someone twenty blocks away that included a dead-on description of one of the chickens. The fowls had crossed the four-lane thoroughfare in front of Gilbert's house as well as several residential city blocks to get to the spot where they were last seen. But by the time Gilbert got there, they were gone.

Despite losing her hens, Gilbert and her husband Jonathan have yet to build a coop in their large back yard for Twitter. But Gilbert isn't worried. "Twitter's afraid of cars," she says. "Sometimes, when I'm in the front digging around, she'll think she sees a worm and will come forward to get it, but then hear the traffic and run to the back of the house."

Such is the life of an urban chicken. Although still something of a novelty, more and more Portland families are taking advantage of the city's ordinance allowing up to three of the animals per household. The local nonprofit Growing Gardens holds a fundraiser called Tour de Coop each year: mimicking standard home tours like Street of Dreams, participants pay \$5 and receive a map of "open coops." On the tour, prospective chicken owners can talk to experienced chicken owners about how to set up their own residential egg and manure productions. The urban chicken-keeping trend is so prevalent that it's been the subject of articles in the New York Times and Time magazine in 2008. And Portland writer Caroline Cummins, who details her chicken- 
raising escapades on the food website Culinate, was once told by a friend, "Chickens are so trendy, they're, like, the new iPod."

Like many urban homesteaders, Gilbert was inspired by Barbara Kingsolver's Animal, Vegetable, Miracle and Alisa Smith and J.B. MacKinnon's Plenty to throw out all the processed, prepackaged food in her cupboards and eat primarily food that she's grown herself or purchased from local farms and farmers markets, which, at the height of summer, number fourteen in the Portland-metro area. Like Kingsolver, Gilbert cuts herself some slack with her local diet, allowing for things like chocolate, salt, coffee, and olive oil, but tries to buy these items only as estate-produced imports.

A typical day for Gilbert is not unlike the usual whirlwind of a modern American family. She wakes up between seven and eight o'clock to the hum and buzz of kids getting ready for the day. Jonathan is on hand to help keep things moving along, so Gilbert, who describes herself as an excellent multitasker, says that four of seven mornings, she starts a project, such as pouring leftover milk into a strainer to make cheese or getting some bread rising so the family will have it eat for supper. If it's milk delivery day, she sets empty bottles in the cooler on her porch and writes a check for that week's order.

By nine o'clock, after the kids are off to school or set up with the nanny, she goes upstairs to work on her blog for a few hours, then comes down to start lunch: perhaps rolling out some leftover pasta dough to cook with homemade ricotta, or smearing some jam on leftover oatmeal bread-both, of course, 
homemade. She then goes back upstairs to work until four, when the nanny leaves. Until eight o'clock bedtime, she spends time with her sons gardening or doing art projects or making dinner. After they go to bed, she works on finishing up that cheese she started in the morning or doing prep for another meal tomorrow. She sometimes has work to finish up for AOL. Perhaps she'll watch some TV and knit.

In keeping with their sustainable ways and because they spend most of their time near home, the family gave up their car last year and rely primarily on bus, bike, and walking to get around town. (When Gilbert went into labor with her youngest son, she caught the bus to the hospital.) Despite the fact that Gilbert doesn't leave her house much on a typical day, she lives a very public life. Aside from her "real" job, she writes her own popular blog (Cafemama) and is also a regular and frequent contributor to several online communities, including Urbanmamas, a Portland parenting site that she helped found, and Culinate, for which she is a guest blogger.

When Gilbert is online, she uses her personal experiences to advocate for a particular lifestyle, whether it's breastfeeding or biking or local foods. Her postings are incredibly candid and descriptive. Portlanders who follow Gilbert online are of two camps: they love and are inspired by her, or they love and are intimidated by her. Some feel annoyed that she ran a relay leg in the Portland Hood to Coast marathon six weeks postpartum, but then sympathize with her because she's so open about her son's difficulties in kindergarten and her decision to begin medicating him. 
Gilbert is often asked how she does it all: mother of three, wife, fulltime blogger, urban homesteader. "It is really hard," she says. "But everything we do is hard, you know? Devoting yourself to Lost is hard. Making your hair look nice takes effort. You pick what you want to spend your time on."

"Part of the thing is that we just don't believe in ourselves. We think we can't do it because that's what people have been telling us," she says, adding that the best part about making most of her food herself is the feeling of mastery. "It turns out that all the things that I thought I wasn't very good at, I just wasn't very educated about it," she says. "When you spend the time to get educated about it, you discover that it's really pretty easy. It's just a little bit time-consuming, so you give up TV and spontaneous vacations."

Gilbert, like authors Kingsolver, Smith, and MacKinnon, is quick to remark that she can't live a local, sustainable lifestyle on her own. She admits that working at home full-time makes it easier for her to do things like make her own bread and cheese, but she also hires a nanny for thirty hours a week, and her husband, who works seasonally as a landscaper and is also an army reservist who's called to active duty twice a year, also helps with childcare and housework.

But she says that her support network goes beyond the walls of her own house: "I can't climb into that tree to harvest my plums," she says, gesturing to a forty-foot tall tree in her larger than average back yard. So she plans to register the tree with the nonprofit Portland Fruit Tree Project, which organizes harvesting parties each year to pick fruit that would normally go to 
waste and distribute it among the homeowners, volunteer fruit pickers, and local food distribution charities. She shares eggs with her neighbors, who in return give her produce from their garden. And when she gets a goat next year, she'll use the milk to make cheese, which she'll share with friends.

"There's a reason that for the bulk of our history, people made their food and shared with their friends," she says. "That's a more sustainable way to live. I bet if you lived in this neighborhood when this house was built in 1912, there was livestock in the back, and people who lived here were sharing chickens with other families. And when they made cheese, they didn't make it just for themselves. They maybe made extra to pay the doctor. Why can't we just extend some of those things? Instead of just paying people in money for babysitting, why can't we just pay them in cheese?"

Like most urban homesteaders, Gilbert is motivated by concern for the environment and disillusionment with the industrial food complex. "We have some serious problems right now," she says. "Either we're going to strip all of our farmland and go into this mode--what's that movie, Blade Runner?where people are running around in anarchy, or we're going to work together. We're going to figure ways that we can create sustainable, agricultural communities and turn back the hands of time and stop eating BLTs in January."

"How bad would it be to able to make your own bread? To have all the skills you need to live comfortably and happily for a couple weeks or a month if something went wrong, an earthquake happened or if we had some terrible 
blackout or some economic crisis and all the stores were shut. Wouldn't that be great if I was the one in the neighborhood who had milk because I had a goat?"

Skepticism and dissatisfaction in an economic system that revolves around the production and consumption of mass-produced goods is at the heart of urban homesteading. As people like the Dervaes family and Sarah Gilbert take back their kitchens and yards, using them once again as political and public spaces, the very shape of the home is changing as well-its borders shifting and stretching in real and ideological ways. In the New York Times article, Jules Dervaes is quoted as saying of his family's now-famous urban homestead, "This is our form of protest, and this is our form of survival."

It's hard to take seriously the criticisms that the microeconomies created by urban homesteading are privatizing the home: rather, it seems these efforts are politicizing the home. Many of these people are extremely vocal about their efforts. Aside from writing about their work and beliefs on their blogs, they are featured in local and national news stories and have acolytes who follow in their footsteps. In these ways, their homes become topics of public discussions and examples of alternative ways of living.

Despite its hominess, it's hard to regard Harriet Fasenfest's kitchen as anything but a public, political space. After all, the owner and founder of Preserve spends nearly every week in summer teaching strangers to make jam 
in her Northeast Portland home. And for Fasenfest, whose motto is "Put up or shut up," jam is political: it's one of the keys to self-reliance and dismantling the industrial food complex that she feels has imprisoned Americans for decades.

One June morning, Fasenfest stood at her stove, surrounded by ten female students-most of us mothers-playing a game of chicken with a saucepan of boiling strawberries. She watched the pot carefully, one hand on the burner knob, the other holding a mixing spoon, which she held poised over the pot but refused to use it to tame the frothy mixture. As the berries bubbled and rose to the top of the pan, she turned the flame down slightly. After the berries settled down a bit, she turned the flame up a little more, urging them to maintain a full boil.

The scene was surprisingly tense for those who were watching, all students in a daylong class on preserving. By the end of the day, we hoped to understand the basics of how to do things like make jam, put up tomatoes, and ferment cabbage into sauerkraut-domestic skills of food preservation that might have been passed down had our grandparents and parents not been saved from such labors from industrialization and large-scale food production.

Watching Fasenfest poised over the stove, a couple of students giggled nervously and exchanged anxious looks. "That would be really hard to clean up," one woman whispered.

"You don't want to stir it?" another woman said hopefully. 
"Nope," Fasenfest said without looking away from the pot. "I don't stir in the first eight minutes because I don't want to break up the boil."

There was absolutely nothing pretentious about Fasenfest's kitchen: no fancy six-burner vanity range with matching vent, no natural stone countertops, no subzero fridge. The only stainless steel in the room was an unusual, shallow, double-bowl sink, which, along with the Formica countertops, dated the kitchen's latest remodel at around mid-century.

In fact, none of the appliances matched, except in that they were all some shade of white. The refrigerator, as in most other kitchens in middleclass American homes, was covered with newspaper clippings and scraps of papers held in place by magnets. The basic gas stove, covered with old cooking stains, probably got the highest rating in Consumer Reports a few years ago or was purchased used off of Craigslist. The room as a whole had the makeshift quality, again, typical of middle-class homes: The butcher-block-topped island didn't have ready access to an outlet, so the cord of a huge electric pot (that would be used for the water bath) draped across the doorway that led to the nook. During the lesson, whenever Fasenfest had to retrieve something from the nook's shelves, she had to lift the cord and duck under it. This wasn't some sort of stainless steel-clad test kitchen a la Top Chef-this the real thing: a home kitchen.

Fasenfest founded Preserve in 2005 with friend Marge Braker, a home economist who worked for years in the Oregon State Extension Services in Corvallis. Fasenfest's path to using her kitchen to teach women to put up fruit 
and vegetables was more indirect. Since moving from the Bronx to Portland in 1978, she's owned a handful of coffee shops in gentrifying neighborhoods, beginning with Bertie Lou's in 1982 and ending with Groundswell Cafe, which she opened in 2000 on Northeast Alberta Street, just a few blocks from her home.

With all of her restaurants, Fasenfest created spaces not just for coffee and muffins, but also for art and politics. She says she sold Groundswell in 2004 when Stumptown, a local coffee roaster that at the time also had a couple of retail stores, put feelers out for a shop near Fasenfest's. "I'd been selling their coffee for years," says Fasenfest, who still bristles when telling the story. "And now they're going to come in and compete with me?" She says that's when she started to realize that small businesses were unsustainable given a larger economic system that encouraged growth and competition. After failing to persuade the city to consider setting up commercial land trusts that would effectively control the costs of commercial space in gentrifying areas in order to keep the market open for small businesses, she decided it was time to retire from life as a small retail business owner.

Fasenfest, who had worked for Habitat for Humanity and organized a salon series that merged art with social activism, then turned her attention to economics and jam. She says her experience at Groundswell got her thinking about economic systems in general: "I obsessed for two years. I couldn't figure out where the breaking point was." Then one afternoon, she was sitting in her back yard writing in her journal when a pear fell to the ground and a light went 
off. "It was like Newton," she says. "I really didn't ever think about those pears but then suddenly I thought, 'Asset."'

That first year, Fasenfest says, she made fruitcake, tons of fruitcake.

Her husband encouraged her to "just let it be fruitcake. Don't manifest." But eventually Fasenfest started "following the dirt" and digging up her entire back yard to plant food. After a couple of years, the large L-shaped yard bore no resemblance to a classic suburban yard: there's now no expanse of green space, just grass in the paths that wind through freeform beds that produce enough fruits and vegetables to support her household (at last count, Fasenfest, her husband, his teenaged son, a grown son, and her mother who was visiting for two months from Florida).

Fasenfest soon realized she needed to preserve the food she was producing. She snooped around and discovered that the Oregon State Extension Service no longer taught food preservation classes, so she tracked down her old friend Braker, who was skeptical that Portlanders would want to learn how to put up food. But Fasenfest persuaded her otherwise, and in 2005, the two opened Preserve, teaching the first two years of their classes in rented commercial space. In 2008, Braker went back into retirement, and Fasenfest taught the seventeen summer classes in her own home. When weather permits, she holds class in the outdoor kitchen-really, just a set of folding tables, a large gas grill, and a makeshift stainless steel sink hooked to hoses with buckets underneath to catch water-built where the carport used to be. 
In addition to teaching students about supplies and techniques, Fasenfest often and easily lapses into diatribes about subverting capitalism. For example, Fasenfest teaches students how to use under-ripe apples to make their own pectin, a complex carbohydrate that helps fruit gel into jam, rather than buying the powdered form at the store, describing the latter as "industrialized jam-making system that got translated for the home." Even to the most discerning audience, she seems to have a point: store-bought pectin requires the addition of an enormous amount of sugar, while homemade pectin, easily made from apples gleaned from a neighbor's tree, requires very little.

Fasenfest says that jam is just one way of "going backwards," of expressing protest against large-scale food production and its depletion of natural resources. This protest is also targeted at governmental policies that encourage capitalism and large, rather than local, economic systems. In this way, urban homesteading, preserving, and other domestic skills, such as knitting and sewing, are expressions of dissent and ways to opt out of larger economies.

Fasenfest believes that at the end of the day, food is the key to breaking out of a system that no longer works. Like other urban homesteaders, locavores, and sustainable food advocates, Fasenfest believes that Americans no longer have a meaningful relationship with food. This can show up in the act of buying strawberries that have been shipped a thousand miles to arrive at a grocery store in March. She also points to the size and cost of people's 
kitchens compared with how little they actually cook, describing a friend who remodels her kitchen every few years although her fridge is stocked with processed food from Costco. "This is a narrative of our disconnect with food," she says. "It's like putting on a party hat when you've got dirty drawers on."

Fasenfest is cautiously exploring partnerships with other nonprofits in hopes of reconnecting people with food and helping them live smaller, more sustainable lives. But she still resists growth in the same way she did as a café owner. When the kitchenware chain Sur la Table tried to entice her to teach a preserve class at the Portland store by saying, "We'll make it worth your while," she was livid.

“Worth my while? Worth my while?" Fasenfest exclaimed, a look of incredulity on her face. "I just wanted to say, 'I don't care about money. That's not what motivates me!"”

She understands that, at some level, more people canning, regardless of how much she got paid to teach them, means more people rebuilding their fractured relationship with food and fewer people buying mass-produced jams-all good things to reach the same noble ends. "But one thing I'd really hate to see," she says, "is some kind of handbook on urban homesteading." For Fasenfest, small economies of the home are political but they're also practical. They are ways of revaluing the domestic skills of the past and bringing people back in touch with the basic needs of their daily lives. Despite her bluster, there's a simplicity and elegance to her message: 
"In August, when the Veteran peaches are in, it's a perfect peach," she says. "I mean, what do you gotta do but eat it?"

At a late summer urban-homesteading hoedown in Fasenfest's garden, Sarah Gilbert showed up on her bike carrying her three sons and potluck dish of hot saffron pudding: she'd ridden six miles-much of it uphill. The pudding was in a large ceramic bowl topped with a plate and strapped closed with nylon straps, like those used on a backpack. The two older boys straddled a board on the back of the bike. The youngest one sat in a BoBike Mini seat secured to the handlebars.

Although it's been months since I'd seen Gilbert, I know all the details about her bike (an Xtracycle Freeradical that extends a bike's frame to accommodate a long board and panniers to make hauling kids and stuff easier) and even her corn pudding because I've read about it online, either on her personal blog or one of the many for which she is a contributor. I also know that she bought her bike in an act of defiance with money from her economic stimulus package, doled out by the federal government in early 2008 to encourage Americans to buy more stuff and keep the economy afloat. She wrote on the website Urbanmamas, an online community for Portland-area parents, that she'd use the check to buy things, but "not the things Bush and big retail corporations wanted me to. My debit card wouldn't be swiped at Target or Sears or Olive Garden. ... I wouldn't buy a single gallon of premium 
unleaded gas, nor sink a nickel into video poker machines. No. I'd buy things that would work gently against big government and big oil."

Gilbert wrote that she would use the money to invest in her "little urban homestead's soil, air, and food stores. I'd get off the grid, just a bit, I'd use it to live lighter." And she encouraged her readers to do the same. In the days that followed, thirty people responded to her posting, saying she'd inspired them to make similar changes in their households. In homes across the city, I'll bet women Googled "Xtracycle" and "urban homesteading," and searched for information about planting fruit trees and raising chickens in the city. 
Five years after buying the little bungalow on $N E 70^{\text {th }}$ Avenue, Alex and I had completed all of the major remodels we'd deemed necessary. Aside from opening up our living area, landscaping the front and back yards, and remodeling the upstairs to make room for our daughter, we'd also completely remodeled the kitchen, tearing out the old cabinets and assembling and installing new ones every night after work for weeks.

By then, of course, it was time to move. The little bungalow had become tight with the three of us: toys lay scattered throughout the house at all hours of the day, my office had been pushed to one corner of the guest room, and Alex began spending more and more time in the unfinished basement and garage, just to get away from the constant activity. Although we'd built close relationships with our neighbors, the original problems of distance from downtown and limited nearby amenities remained.

We began doing drive bys and visiting open houses again, but this time with our preschooler in tow. Gone were the hours and gallons of gas spent meandering through the city's charming neighborhoods: now, we were limited to one-hour chunks of time before Stella grew impatient and began thrashing in her car seat or, worse, dismantling a strangers' perfectly staged home.

Also different this time around was the tempo. Houses languished for months. Buyers visited and revisited homes again and again, taking their time before making an offer-something unheard of in the early 2000s. In this slow 
market, the asking prices of the big early-1900s houses on the inner eastside's grand tree-lined streets began dipping into our price range. One cold, rainy October, Brad took me to see a vinyl-covered 1905 fixer in the Sunnyside neighborhood, nestled between the bustling Belmont and Hawthorne districts only thirty blocks from downtown. It had been on the market for months, woefully overpriced for that year's post-mortgage crisis/pre-recession market.

As Brad finished up a call on his cell phone, I sat on the swing and admired the generous stretch of the porch. I got up and looked through the grimy windows and saw an open staircase in the entry hall and a corner fireplace in the living room. The rooms seemed expansive compared to the tight rooms of our bungalow, the ceilings at least a foot taller. I walked to the edge of the covered porch and felt boards sag below my feet. Up and down the street, huge old trees were losing their leaves. Even before Brad got off the phone and let me in to the cold, dark house, I could see Stella scrambling through the wide front door and up the stairs to her room. I could see her running circles through the big family kitchen and dining room and living room and back again. Though Alex had yet to see the place, I knew it had the kind of good bones and raw potential that would intrigue him. It was more of a fixer than our previous house, and the thought of heading down that road again seemed ridiculous, but I knew we'd buy the house.

We moved away from our beloved NE $70^{\text {th }}$ Avenue neighborhood and into the more dense, urban Sunnyside neighborhood to Main Street (appropriately enough) in December of 2007. By summer of 2008, we had 
again begun what would be a years-long process of transforming the house into something that better suits our personalities, tastes, and lifestyles.

In those first weeks, whenever Stella complained of missing her neighborhood friends-children she'd known literally since the day she was born-and asked why we had moved. I told her, somewhat romantically, that we wanted to be closer to the city that we love. Not that Portland is one citydowntown. It is actually a series of hamlets: small quaint neighborhoods that resemble small quaint towns, hubs around which residences cluster. Our neighborhood for the past five years has had all of the characteristics of such a small town: people who knew ours name, businesses that we relied upon for services, parks with play equipment that my daughter, month by month, learned to master.

But living in such a community is different from living in the city. In moving to Main Street-with its higher density, few owner-occupied homes, a more diverse range of income levels and ages-we'd clearly traded one kind of public life, that of coexisting with neighbors who are like extended family, for another, that of coexisting with strangers in an urban core. Admittedly, on the surface, this didn't seem like a very good exchange. But we'd grown complacent on NE $70^{\text {th }}$, used to stepping out the front door and into easy social interactions that, while comfortable, had become inward-looking, homogenous, and predictable. Our sense of obligation, though it extended beyond the walls of our own home, went no farther than to neighbors' homes, which we'd come to know as well as our own. In essence, we'd become good 
neighbors but indifferent citizens, concerned primarily with life on our few blocks. In moving to Main Street, we hoped to gain a stronger sense of the city-and even the world-as our home.

We threw ourselves into the social experiment. We spent less time in the bubble of our car, instead walking, riding our bikes, and busing everywhere: to work, to the library, to parks, to get our CSA vegetables, to stores, coffee shops, restaurants, and movies. In our new dense neighborhood, it was easier to build a network among more diverse entities: farmers markets and local buying groups and coops for food, thrift and second-hand stores for clothing and home goods, mom-and-pop shops for everything else. Our relationship with the city intensified and localized. We came to understand the rhythms and patterns of many lives rather than only a few.

Unlike when we first moved to $\mathrm{NE} 70^{\text {th }}$, we immediately reached out to our new neighbors on Main Street and invited them into our lives. We set ourselves up as the neighborhood delivery drop for a local organic dairy. Every Monday, the milkman delivers milk in glass bottles to coolers on our porch, and after work on those days, we visit with neighbors and friends as they stop to pick up their orders.

We began stopping at the nearby farmers' market weekly after work, getting to know the vendors and relying on them to supplement the food we were getting from our CSA. We joined Rebecca Andersson's bulk food and grass-fed meats buying groups. We spent many warm summer nights in our hot kitchen, using Harriet Fasenfest's techniques to cook fruit into jam, 
plunging full jars into a boiling cauldron of water. The shelves of our basement pantry are lined with fruit, jams, and chutneys; the freezer in the garage is full of frozen vegetables, grass-finished beef, and berries. We cut back our trips to grocery stores from once a week to once a month. We stopped buying bananas because they come from too far away. Sometimes, like Sarah Gilbert, we made our own cheese.

And, in keeping with the tradition of the public house, I started a blog and opened Twitter and Facebook accounts. I wrote about our adventures in home improvement, food preservation, marriage, and parenting. I read about other people's adventures and sometimes commented on them. But I was shy to talk to friends about the ways in which our lives have changed because I worried that I'd come off as self-righteous, a smug Portlander. Instead, I told them stories about the people I'd met and interviewed for this book. I shushed Stella when she wondered why a restaurant has peaches in July, even as I felt a surge of pride at how much she'd gleaned about the world from within the embrace of our small daily lives.

Next year, with Stella's blessing, I want to tear down the play structure that blocks half a day's sunlight and takes up fifty-square-feet, and plant a garden instead. In fact, I want to tear up the entire yard and put in fruit trees and vegetables. Alex has been game and supportive so far, but fears I will keep slipping down this path, dragging the family with me. He worries I'll come home one day with chickens. 
While I work to make our daily lives more sustainable and solidify our ties to the neighborhood and city, Alex transforms our house. It took the two of us one evening in August to tear the lath and plaster from the load-bearing wall between the kitchen and the dining room, but two months to get the plans from the engineer telling us how big a beam we'd need to hold the house up. For three months, we've lived in an undone house, but none of us seemed to mind. Soon enough, we'll have an open floor plan in a hundred-year-old house, and then we'll move on to the next project.

In the meantime, we carefully step around the three-hundred-pound beam sitting on sawhorses in the middle of the kitchen. Stella eats her cereal amid the exposed hundred-year-old two-by-fours and rafters of the dining room. Friends and neighbors come and go. The mess of a house and a life so visibly, so perpetually, in progress don't seem to trouble them either. They must know that we are in our natural habitat. 


\section{Works Cited}

Alexander, Christopher, Sara Ishikawa, and Murray Silverstein. A Pattern

Language: Towns, Buildings, Construction. New York: Oxford

University Press, 1977.

Andersson, Rebecca. Personal interview. 21 Aug. 2008.

Bachelard, Gaston. The Poetics of Space: The Classic Look at How We

Experience Intimate Places. Boston: Beacon Press, 1994.

Brand, Stewart. How Buildings Learn: What Happens After They're Built.

New York: Penguin Books, 1994.

Brooks, David. Bobos in Paradise: The New Upper Class and How They Got

There. New York: Simon \& Schuster, 2000.

Busch, Akiko. Geography of Home: Writings on Where We Live. New York:

Princeton Architectural Press, 1999.

De Botton, Alain. The Architecture of Happiness. New York: Pantheon, 2006.

Fasenfest, Harriet. Personal interview. 30 Jul. 2008.

Fortin, Ellen. Personal interview. 11 Jan. 2008.

Gallagher, Winifred. House Thinking: A Room-by-Room Look at How We

Live. New York: Harper Collins, 2006.

Garber, Marjorie. Sex and Real Estate. New York: Pantheon Books, 2000.

Gilbert, Sarah. Personal interview. 17 Mar. 2008.

Gragg, Randy. Personal interview. 16 Aug. 2007. 
Habermas, Jurgen. “The Public Sphere." Rethinking Popular Culture:

Contemporary Perspectives in Cultural Studies. Ed. Chandra Mukerji and Michael Schudson. Berkeley: University of California Press, 1991. 398-404.

Hochman, David. "Mommy (and Me)." New York Times 30 Jan. 2005

Holloran, John. "Home Economics," Oregon Humanities Fall/Winter 2007: 47-52.

Jesella, Kara. "Blogging's Glass Ceiling." New York Times (27 Jul. 2008). 19

Aug. $2008<$ http://www.nytimes.com/2008/07/27/

fashion/27blogher.html>.

Johnson, Robert. “Why New Urbanism Isn't for Everyone," New York Times, 20 Feb. 2005.

Joint Center for Housing Studies. Good Home Improvers Make Good

Neighbors. Cambridge, MA: Harvard University, April 2008.

Joint Center for Housing Studies. A Long-Term Outlook for Homeowner

Remodeling Activity: Results and Implications. Cambridge, MA:

Harvard University, August 2007.

Kelley, Rebecca. Personal interview. 21 Aug. 2008.

Kolbert, Elizabeth. “Turf War.” New Yorker 21 Jul. 2008: 82-86.

Langdon, Philip. A Better Place to Live: Reshaping the American Suburb.

Amherst: University of Massachusetts Press, 1994.

Leach, William. Country of Exiles: The Destruction of Place in American Life.

New York: Vintage Books, 2000. 
Maddex, Diane and Alexander Vertikoff. Bungalow Nation. New York: Harry N. Abrams, Inc., 2003.

"Mapping." This American Life. Chicago Public Radio. WZEI, Chicago. 19 Oct. 2007.

McAlester, Virginian and Lee. A Field Guide to American Houses. New York: Knopf, 1984.

Oldenburg, Ray. The Great Good Place: Cafes, Coffee Shops, Bookstores, Bars, Hair Salons, and Other Hangouts at the Heart of a Community. New York: Marlowe \& Company, 1999.

Postrel, Virginia. The Substance of Style. New York: HarperCollins, 2003.

Putnam, Robert D. Bowling Alone: The Collapse and Revival of American Community. New York: Simon \& Schuster, 2000.

Rybczynski, Witold. Home: A Short History of an Idea. New York: Penguin, 1987.

Sheets, Brian. Personal interview. 8 Aug. 2008.

Shiels, Maggie. "The Power of Female Blogging." BBC News (8 Aug. 2008) 19 Aug. 2008 <http://news.bbc.co.uk/2/hi/technology/ 7534249.stm>.

Sullivan, Robert. “Home Wrecked.” New York Times Magazine 7 Mar. 1999: 19-20.

Surowiecki, James. “Home Economics,” New Yorker. 10 Mar. 2008: 62.

Tauber, Daveena. "Home/Work," Oregon Humanities. Fall/Winter 2007: 2225. 
Zinko, Carolyne. "It's a Woman's World Wide Web." SFGate.com (17 Aug. 2008). 19 Aug. $2008<$ http://www.sfgate.com/cgibin/article.cgi?f=/c/a/2008/o8/15/LVK811GDD8.DTL>. 